Article

\title{
Use of Automated Control Systems and Advanced Energy Simulations in the Design of Climate Responsive Educational Building for Mediterranean Area
}

\author{
Fabio Fantozzi ${ }^{1}$, Hassan Hamdi ${ }^{2}$, Michele Rocca ${ }^{1, *}$ and Stefano Vegnuti ${ }^{1}$ \\ 1 Department of Energy, Systems, Territory and Constructions Engineering, University of Pisa, 56122 Pisa, \\ Italy; f.fantozzi@ing.unipi.it (F.F.); stefano.vegnuti@gmail.com (S.V.) \\ 2 National Centre of Studies and Research on Water and Energy, Cadi Ayyad University, Marrakesh 40000, \\ Morocco; hhamdi@uca.ac.ma \\ * Correspondence: michele.rocca.au@gmail.com; Tel.: +39-050-221-7104
}

Received: 20 February 2019; Accepted: 14 March 2019; Published: 19 March 2019

check for updates

\begin{abstract}
Over the decades, a rapidly changing climate has prompted the world's most influential leaders and institutions to take action against such an imminent threat. The introduction of Nearly Zero Energy Building (nZEB) concept, though, has barely triggered a major shift, while voluntary labelling systems do not seem to offer any reasonable alternative. Building design ought to be readdressed from the ground up, with climate-responsive constructions servings as a valuable starting point for the purpose. In this paper, conventional bioclimatic design is enhanced and supported by the introduction of Building Automation Control Systems: Typically, the former determines long-term seasonal patterns, whereas the latter only affects the short-term behavior. Their schedules are based on realistic assumptions, while set-points are fine-tuned following energy simulations. Good results have been achieved for a case-study facility in Porto, both in terms of indoor adaptive thermal comfort (the simulated operative temperature complies the adaptive comfort model for more than $98 \%$ of the reference year) and energy use (reduced by $53 \%$, compared to a baseline building, devoid of any automation system). Being focused on the decision-making rather than on specific items of design, the authors claim that such an approach may be employed in any climate, regardless of the building type or size, as long as the process is driven by a genuine analysis of the local context (i.e., climate) and by purposefully devised energy simulations.
\end{abstract}

Keywords: climate responsive building; advanced energy simulation; automated control systems; building automation; Mediterranean climate

\section{Introduction}

Energy efficiency is today no longer just a question of money, but instead a way to reduce the emissions of greenhouse-gases, commonly held to be responsible for global warming [1]. According to the statistics, buildings account for about $25 \%, 23 \%$, and $26 \%$ of, respectively, Europe's, Portugal's, and Italy's primary energy use [2], and although the housing sector should be blamed for that, it is up to the public realm to set a good example.

As per the plan "202020", introduced by the 2009/29/CE Directive [3], primary energy use and CO2 emissions shall be reduced by $20 \%$ within 2020 . To this end, the $2010 / 31$ /EU Directive [4], the recast of the original EPBD, introduced the so-called Nearly Zero Energy Building ("nZEB") concept; unlike Zero Energy Buildings ("ZEBs") and Plus Energy Buildings ("PEBs"), nZEBs are grid-connected, "high performance buildings, whose low amount of required energy is extensively 
supplied by renewable energy sources" [5]. Newly designed public buildings must be nZEBs starting from $01 / 01 / 2019$, while private developments from $01 / 01 / 2021$ onwards only.

In spite of this, the nZEB is more of a regulatory concept; it was up to each country to come up with a suitable definition $[5,6]$, which has normally been encompassed within the national energy labelling framework [7]. In Italy, according to the Law n ${ }^{\circ}$ 90/2013 and its Implementing Decrees (Date of issue: 26th of June 2015), a nZEB must comply with very high requirements (as far as envelope and HVAC systems are concerned) and cover at least 50\% of its energy and DHW demand with on-site renewable energy sources. The Laws $n^{\circ} 118 / 2013$ and $n^{\circ} 250 / 2015$ make similar provisions in Portugal. It is no operative tool and it cannot yield, therefore, any qualitative guideline. Voluntary rating systems [8], such as PassivHaus [9-15] and LEED [16], were introduced long before the nZEB, in 1988 and 1998, respectively. The latter is based on credits; it was conceived in the USA, but has eventually caught on in Europe. The former, which unlike LEED, is based on performance evaluation, was developed in Central Europe and later adapted to other climate zones, either colder or warmer, thanks to institutional efforts (EU's C.E.P.H.E.U.S. project, [17]) as well. Nonetheless, climate change and heat waves, which occur nowadays at an alarming rate [18] and whose effects we are now beginning to experience, force us to reconsider the way buildings are designed. Otherwise, they are inevitably going to suffer from overheating, and require larger HVAC systems to compensate for higher cooling loads even in traditionally cold climates, as anticipated in several studies [10-12,19,20]. Unfortunately, both labelling and regulatory systems belong in the last steps of the design-process, and have no influence whatsoever on the preliminary stages, when the most influential decisions are made; designers should therefore reject an assessment-oriented attitude in order to embrace a more holistic approach to design, both on the building [21] and on the urban [22] scale. Bioclimatic design [23] should be the stone upon which to build a more systematic approach to design. Although frequently confused with sheer environmental design, it is a century-old discipline, which prefers the context over the concept; bioclimatic constructions are carefully crafted on a case-by-case basis following a well-defined hierarchy, taking advantage of their immediate surroundings in order to reduce their environmental footprint.

Several studies have been concerned about this topic: Soutullo et al. [19] compared conventional and bioclimatic buildings, Rodriguez-Ubinas et al. [20] concentrated on the prototypes from Solar Decathlon Europe 2012, while Tzikopoulos et al. [24], found correlations among the energy indicators of 77 bioclimatic buildings.

In the past decades, the topic of climate-based design for buildings has been widely studied and discussed, up to the importance of having buildings resilient to climatic conditions. Despite this attention, the sheer volume of studies and also the many different directives and national laws issued nationally in the Mediterranean countries have not succeeded in creating clear, shared, and generalizable methodological approaches, useful for guiding the design stage of architects and building engineers.

With this contribution, the Authors wish to show how is possible to obtain remarkable energy performance for Mediterranean buildings, both in winter and summer season, combining traditional construction techniques with automatic regulation and control systems. In particular, this goal is obtained basing the design choices on the possibility of modifying some properties of the building envelope (appropriately managed by building automation control systems) and of bringing accurate dynamic energy simulations into the design process. This approach is applied to a real case study, which is not by chance, a partially underground academic facility in Porto (Portugal), whose only exposed facade - the Southern elevation-acts as the main control device. The building employs some passive solar design features, among which is a considerable amount of thermal mass, which well-justifies a dynamic analysis of heat exchange phenomena. 


\section{Materials and Methods}

\subsection{Case-Study Location}

The Porto School of Architecture (or FAUP: Faculdade de Arquitectura da Universidade do Porto) is located on the Campo Alegre University Campus and was designed during the second half of the 1980's by Álvaro Siza Vieira [25]. It consists of four towers of classrooms facing South and a long shallow block to the North, which houses the offices, the library and the auditorium; the two are connected on the ground floor by a slab containing technical rooms. In the last decades, the faculty has grown exponentially; a new canteen had become indispensable, while the surrounding areas must be freed from invasive parking spaces. An extension, designed of as an independent new wing (along with the design process) will provide enough space for a new catering service as well as a larger study room.

The climate variables, for the case-study location, were analyzed and averaged over each month (Table 1); on this basis, the Köppen label [26] was determined together with the number of heating and cooling degree-days (Table 2).

Table 1. Climate data: Monthly means of climate variables.

\begin{tabular}{|c|c|c|c|c|c|c|c|c|}
\hline \multirow{2}{*}{ Month } & $\mathrm{T}_{\mathrm{AIR}, \mathrm{MM}}$ & $\mathrm{T}_{\mathrm{A}, \mathrm{MIN}, \mathrm{MM}}$ & $\mathrm{T}_{\mathrm{A}, \mathrm{MAX}, \mathrm{MM}}$ & $\mathrm{T}_{\mathrm{GRO}, \mathrm{MM}}$ & $\mathbf{I}_{\mathrm{H}, \mathrm{HM}}$ & $\mathbf{R H}_{\mathbf{M M}}$ & $\mathrm{V}_{\text {WIND,MM }}$ & D WIND,MM $_{\text {MI }}$ \\
\hline & ${ }^{\circ} \mathrm{C}$ & ${ }^{\circ} \mathrm{C}$ & ${ }^{\circ} \mathrm{C}$ & ${ }^{\circ} \mathrm{C}$ & $\mathrm{Wh} / \mathrm{m}^{2}$ & $\%$ & $\mathrm{~m} / \mathrm{s}$ & ${ }^{\circ}$ NORTH,CW \\
\hline January & 9 & 0 & 17 & 12 & 187 & 80 & 2 & 100 \\
\hline March & 12 & 1 & 21 & 11 & 346 & 78 & 3 & 185 \\
\hline April & 13 & 5 & 26 & 12 & 425 & 76 & 3 & 194 \\
\hline July & 19 & 10 & 32 & 17 & 457 & 80 & 3 & 229 \\
\hline August & 19 & 10 & 31 & 18 & 450 & 76 & 2 & 163 \\
\hline September & 18 & 9 & 30 & 18 & 374 & 81 & 1 & 202 \\
\hline October & 16 & 6 & 27 & 17 & 293 & 76 & 3 & 168 \\
\hline November & 12 & 1 & 20 & 15 & 181 & 80 & 3 & 157 \\
\hline
\end{tabular}

Note- $\mathrm{T}_{\mathrm{AIR}, \mathrm{MM}}, \mathrm{T}_{\mathrm{A}, \mathrm{MIN}, \mathrm{MM}}$ and $\mathrm{T}_{\mathrm{A}, \mathrm{MAX}, \mathrm{MM}}$ are, respectively, the monthly mean air temperature and its recorded minimums and maximums, $\mathrm{T}_{\mathrm{GRO}, \mathrm{MM}}$ is the monthly mean ground temperature, $\mathrm{I}_{\mathrm{H}, \mathrm{HM}}$ is the monthly mean global solar radiation, $\mathrm{RH}_{\mathrm{MM}}$ is the monthly mean relative humidity, $\mathrm{V}_{\mathrm{WIND}, \mathrm{MM}}$ is the monthly mean wind speed and $\mathrm{D}_{\text {WIND,MM }}$ is the monthly prevailing wind direction (measured clock-wise in degrees North).

Table 2. Climate data: Characterization of the climate type.

\begin{tabular}{cccc}
\hline Location & Köppen & HDD & CDD \\
\hline Porto (Airport) & Csb & 1566 & 11 \\
$41.23^{\circ} \mathrm{N}, 8.68^{\circ} \mathrm{W}$ & & $\left(\mathrm{T}_{\mathrm{REF}}=20^{\circ} \mathrm{C}\right)$ & $\left(\mathrm{T}_{\mathrm{REF}}=26^{\circ} \mathrm{C}\right)$ \\
\hline
\end{tabular}

Note: "Csb" indicates a less common form of Mediterranean climate. " $\mathrm{C}^{\prime}:$ mean temperature of the coldest month above $-3^{\circ} \mathrm{C}$; " $\mathrm{s}$ "; rainfall during winter is at least three times in summer; " $\mathrm{b}$ "; mean temperature of the hottest month is below $22^{\circ} \mathrm{C}$. HDD and CDD are heating and cooling degree days, calculated based on $\mathrm{T}_{\mathrm{REF}}$, according to the ISO EN 15927-6/2007 regulation (Hygrothermal performance of buildings-Calculation and presentation of climatic data-Part 6: Accumulated temperature differences. Degree Days).

Results were obtained from the WEC v1.0 dataset of the American Society of Heating and Air Conditioning Engineers (ASHRAE), relating to the Pedras Rubras weather station (Porto's Francisco Sà Carneiro Airport) and artificially made up of data collected between 1982 and 1999 [27]. Porto presents windy, heating-dominated climate, an assumption confirmed by its "Csb" classification; this ensues from its proximity to the Atlantic Ocean, whose large thermal mass mitigates both heat and peak waves, keeping temperatures quite low in the summertime. 


\subsection{Design Approach}

The design approach of a climate responsive building aims at shifting the attention from late assessment procedures to the earliest stages of the process, when each choice has a great influence on the outcomes, both in terms of quality and costs. As information about the surrounding context is processed from the beginning, the building can be designed to exploit the climate conditions in its favor, in order to reduce its energy use. The design of a climatic responsive building steps beyond regulations, concepts and ratings systems, to look at the bigger picture, and to unveil site-specific synergies that would otherwise pass-by unnoticed [28]. An intuitive hierarchy guides the whole process, prioritizing passive over active design; this choice can generally save some of the costly and exasperated equipment that is sometimes needed in poorly designed buildings. Taking cue from past experience and previous case-studies, as well as from guidelines and rules of thumb [23,29], these strategies have been translated into a technically feasible solution. The background of each strategy and its influence on present-day rating systems and regulations are discussed in the following subsections.

\subsubsection{Orientation}

In temperate climates, buildings have always been shaped as elongated South-facing blocks, which guaranteed maximum and minimum gains in winter and summer, respectively (Figure 1). Modern studies [30,31] confirmed that an East/West elongation is an optimal compromise; in particular, those who focused on Compactness [32] or South Shape Factor [33] have observed that the energy use increases with the East and West façade areas. Ourghi et al. [34] found further correlations amongst glazing type, glazing area, and energy use. In this case-study, the building replaces the former parking lot, whose shape is conveniently long and narrow (the ratio between sides is above 9) is and slightly tilted $\left(12^{\circ}\right)$ from the East/West axis (Further data can be found in Table 6). As a comparison, LEED credits are awarded to buildings whose long sides are at least 1.5 times the short ones, and whose long axis are tilted less than $15^{\circ}$ from the East/West axis. The shape and orientation of the building are generally site-specific, as hot and cold climates require both compact volumes with few openings, while humid areas call for long and permeable structures.

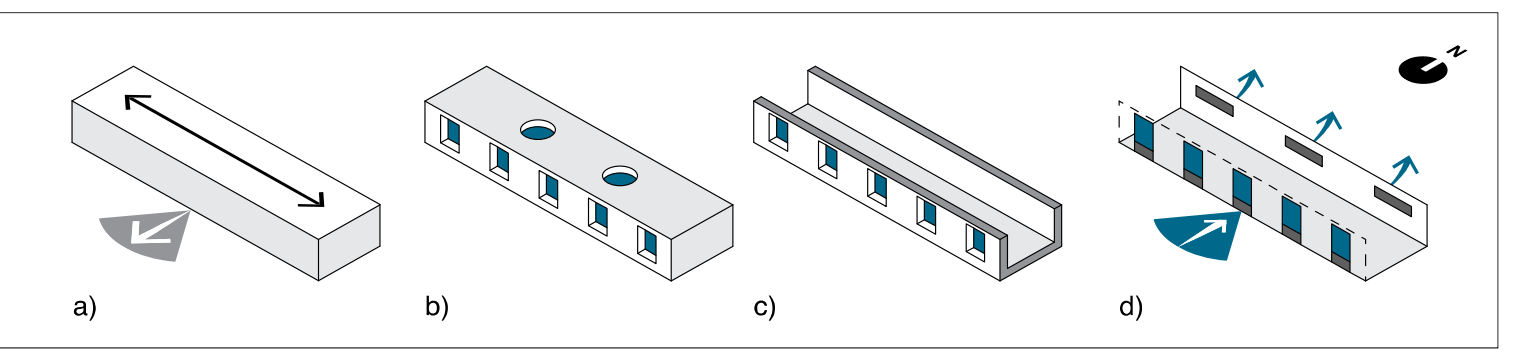

Figure 1. Bioclimatic strategies-(a) Orientation/form finding, (b) daylighting, (c) passive solar design and thermal mass, and (d) natural ventilation.

\subsubsection{Daylighting}

Especially in public buildings, lighting is often what contributes most to the energy use [35-39]. It is therefore preferable to exploit daylight (Figure 1b), which is loosely site-specific, as sky conditions depend on latitude, while the Sky View Factor varies from site to site according to surrounding buildings and topography. Side-lighting is a common solution, but unless patios and courtyards are used, room depth should be limited to 2.5 times its height, as suggested in the EN 15193-1/2017 (Energy performance of buildings-Energy requirements for lighting-Part 1: Specifications). Top light (roof monitors, clerestories, skylights, or solar tubes) is usually uniform and glare-free, but only suitable for large open spaces on the top floors. In the case-study building, South-facing side windows, sized to $20 \%$ of the floor surface, provide a connection to the outside, yet blocking direct light during summer. Translucent skylights, on the other hand, release an evenly distributed and glare-free top-light into the 
building. While innovative concepts based on advanced daylight simulation based on climate based daylighting modelling, such as Spatial Daylight Autonomy and Annual Sunlight Exposure (ASE) are frequently used in advanced daylight simulation [40-43] and they have also been recently adopted by LEED; the Daylight Factor was taken in this case as the reference metric; benchmarks are shown in Table 3, while actual calculated values can be found in Table 6.

Table 3. Building design: Thermal zones.

\begin{tabular}{lccccccccc}
\hline & \multirow{2}{*}{ ID } & $\mathbf{S}$ & $\mathbf{V}$ & Occupants & Weekday & Weekend & $\mathbf{A C H}$ & $\mathbf{E}_{\mathbf{M}}$ & $\mathbf{D F}$ \\
\cline { 3 - 9 } & & $\mathbf{m}^{\mathbf{2}}$ & $\mathbf{m}^{\mathbf{3}}$ & $\mathbf{n}^{\circ}$ & $\mathbf{h}$ & $\mathbf{h}$ & $\mathbf{V o l} / \mathbf{h}$ & $\mathbf{l x}$ & $\mathbf{\%}$ \\
\hline $\mathbf{A 1}$ & Study room & 370 & 1590 & 110 & $08-24$ & $08-18$ & 3.0 & 500 & 3 \\
$\mathbf{A 2}$ & Hallway & 56 & 148 & 5 & $08-24$ & $08-18$ & 1.5 & 200 & 1 \\
$\mathbf{A 3}$ & Common room & 56 & 148 & 10 & $08-24$ & $08-18$ & 3.0 & 200 & 1 \\
$\mathbf{A 4}$ & Corridor & 166 & 510 & 5 & $08-24$ & $08-18$ & 0.5 & 100 & 1 \\
$\mathbf{B 1}$ & Canteen & 521 & 1820 & 240 & $10-16$ & Closed & 6.0 & 300 & 2 \\
\hline & Total & 1170 & 4216 & 400 & & & & &
\end{tabular}

Note- $\mathrm{S}$ is the surface. $\mathrm{V}$ is the Volume. ACH is the air change rate, whose minimum target value is determined according to the EN $13779 / 2007$. $E_{M}$ is the maintained average illuminance, whose minimum target value is determined according to the EN 12464-1/2011. DF is the daylight factor, whose minimum target value is determined according to the UNI 10840/2007.

\subsubsection{Insulation/Glazing}

Thermal insulation controls both heat transfer and water vapor diffusion through the envelope. Current regulations, revised in the wake of the EPBD, do not specify insulation requirements, but rather limits (based on the climate zone) the surface mass, to the local and global (wall and building levels) thermal transmittance and (limited to glazing) to solar factor. Reference values can be found for both walls and glazing in Table 5. In rating systems such as PassivHaus, although thick insulation and triple glazing have always been considered as fundamental, requirements that are indirectly expressed in the form of energy loads and demand thresholds.

\subsubsection{Passive Solar Design}

The Sun is the oldest and most efficient heating system known to man. While solar design can be applied everywhere, it must be regarded as site-specific: Hot regions, arid or humid, needs no heat, while in cold areas, the required amount of radiation is proportional to the outdoor mean temperature of the cold season. There are different ways in which passive solar gain (Figure 1c) can occur, among which direct gain, as opposed to indirect gain, is the simplest; in any case, however, measures must be taken against glare and overheating. In a PassivHaus, South windows should be large and present a high solar factor, balanced out by a very low thermal transmittance. LEED, on the contrary, assigns credits if the surface of South windows is carefully shaded in summer, and at least $50 \%$ larger than the sum of East and West window surfaces. In the case-study building, glazing is located on the roof and to the South only; skylights have a highly reflective external surface, while windows, sized to $20 \%$ of the floor surface (matching the need for daylighting as well) and conveniently set back from the façade, block direct sun during the hottest periods of the year. Additional data, such as Window-to-Wall ratios and Glazing ratios, can be found in Table 6.

\subsubsection{Thermal Inertia}

The benefits of thermal inertia (or thermal mass) have been studied extensively, often in connection with layering [44]. It is not a coincidence that architecture has been, for the most part, "heavyweight" [37] in the past; nowadays, superlight glazed envelopes and curtain walls are catching on dramatically, and will eventually cause the increase, even in temperate climates, of heating and cooling loads. Adequate mass has beneficial effects in many climates, except for humid regions; in cold areas, it collects excess heat during the day and returns it back at night-time, while in hot-arid 
regions, it shifts the peak waves towards the evening; even so, neither LEED nor PassivHaus make any provision in this direction. Some requirements set by the Italian legislation can be found in Table 5 . Literature [29] suggests massive surfaces, less than $10 \mathrm{~cm}$ thick and large up to nine times the floor area. If thermal mass is part of the outer envelope, correct layering is also important [44-48]. If the system operates intermittently, insulation must be placed on the inside (heating dominated climates) or the outside (cooling dominated climates). For a continuously operating system, insulation should be external, and the mass should be at least $25 \mathrm{~cm}$ thick [49]. In the case-study building, both structural concrete walls $(26 \mathrm{~cm}$ thick) and exposed concrete floor slabs $(10 \mathrm{~cm}$ thick) act as thermal mass, with the overall storage surface adding up to more than $1700 \mathrm{~m}^{2}$.

\subsubsection{Natural Ventilation}

Vernacular architecture has always counted on natural ventilation (Figure 1d), despite its scarce dependability, as mechanical air change was not yet possible; primitive examples of evaporative cooling or underfloor heating were already being used centuries ago. The correct approach depends on the location, while in colder climates, mechanical ventilation and heat recovery are employed out of necessity, in temperate regions most houses are in fact free-running [50], although the results of some studies have supported the use of natural ventilation in office buildings [51,52]. It is therefore not surprising that PassivHaus leaves no room for natural ventilation, while LEED refers to either ASHRAE Standard 62-1/2010 (Ventilation for Acceptable Indoor Air Quality) or other equivalent local regulations. In Europe, the EN 13779/2007 (Ventilation for non-residential building-performance requirements for ventilation and room-conditioning systems) requires, for an "IDA 2" class (New buildings), an air change rate of at least $12.5 \mathrm{~L} / \mathrm{s}$ per person. The required air change rates, expressed in terms of volumes per hours, can be found in Table 3, while actual air renewals, determined using energy simulation, are discussed in the following section (Section 4.6, Figure 13) There are very few guidelines for natural ventilation, proper orientation (within $45^{\circ}$ of prevailing winds), vent size (outlets should be larger than inlets, placed on opposite sides and at different heights; actual values can be found in Table 6) and space arrangement (the airflow should be unobstructed).

In Porto, strong winds come mainly from the South and North-West, while cold winds blow from East; the vents were therefore placed on the South façade and on the roof (facing North), in order to trigger both cross and stack ventilation.

\subsubsection{Building Automation Contribution}

Building Automation Control Systems (BACS), in the form of sensors and actuators, have long since become cheap and user-friendly devices, as well as an essential feature of any modern energy-efficient building. Their contribution is strictly affected, however, by the occupants' behavior [53,54], which may easily deviate from the optimal (users tend to override automated devices). In fact, although seemingly illogical, a Danish study [55] reported that more than $60 \%$ of people still prefer, on average, manual controls for lighting, ventilation, and solar shading. Other studies [56,57] have detected the perception of loss of control amongst those occupants, whose workplaces were fitted with automated shading devices, blinds, and light controls. BACS are contemplated by LEED in so far as they help meet other requirements, such as reduced energy use and light pollution through scheduling and occupation control or real-time monitoring and metering. In this case-study, BACS have been embedded into all those components, whose behavior directly influences one or more of the aforementioned strategies (see the Hierarchy in Section 2.3): automated solar shading (Passive solar design and Daylighting) automated operable vents (Natural ventilation) and automated light controls (Daylighting and Energy efficiency). Control strategies and set-points are optimized and further discussed within Section 3 in light of energy simulation. 


\subsection{Technical Solutions Chosen for the Case Study}

Based on the guidelines contained in the previous subsections, a design proposal was outlined (Figure 2). The result is a partially underground construction, located South of the School's premises, in place of the existing outdoor parking lot. The building's only exposed façade overlooks the river Douro and conceals a canteen, a study room, and an underground parking space. Passive design maximizes solar gains, while the underground volume minimizes losses, thus taking advantage of internal gains and protecting the envelope against the rainy and windy weather. Different kinds of opening, including skylights and domes, provide the indoor space with plenty of daylight, while carefully placed vents help reduce overheating, triggering both cross and stack ventilation. Only a portion of the whole building, highlighted in red in the floor plan in Figure 2, was further analyzed from the energy point of view (see Section 3). Figure 3 visualizes thermal zones and envelope assemblies; the latter are fully characterized in Tables 3-5, and are not further optimized. Table 6 summarizes reference values and data for both the opaque and the glazed envelope, and as usual [12,20,21], surface ratios and indexes were used to characterize the building layout and geometry.

In order to enhance the behavior of this reference building a series of advanced energy simulations were carried out using EnergyPlus ${ }^{\mathrm{TM}}$ simulation software. In detail, with the results of the simulations, BACS schedules and set-points can be tuned and optimized, to achieve satisfactory indoor comfort conditions and a reduced energy use. A conventional energy analysis would be impossible to carry out; the effects of thick insulation and thermal mass can only be appreciated on a long-term basis, whereas internal and solar gains have an almost immediate influence on the energy demand-response balance. As in other case-studies $[11,12,18,19,21,28]$, energy simulation has been extensively employed all throughout the process; simulations provided a first feedback, on which basis further control strategies and schemes were devised. As most design strategies must be regarded as site-specific, there are neither invariable criteria, nor representative indicators to be given. However, even though this study concentrated on a single case-study, an educational facility, the process can be seamlessly adapted to other climates and applied to buildings of different sizes and types.

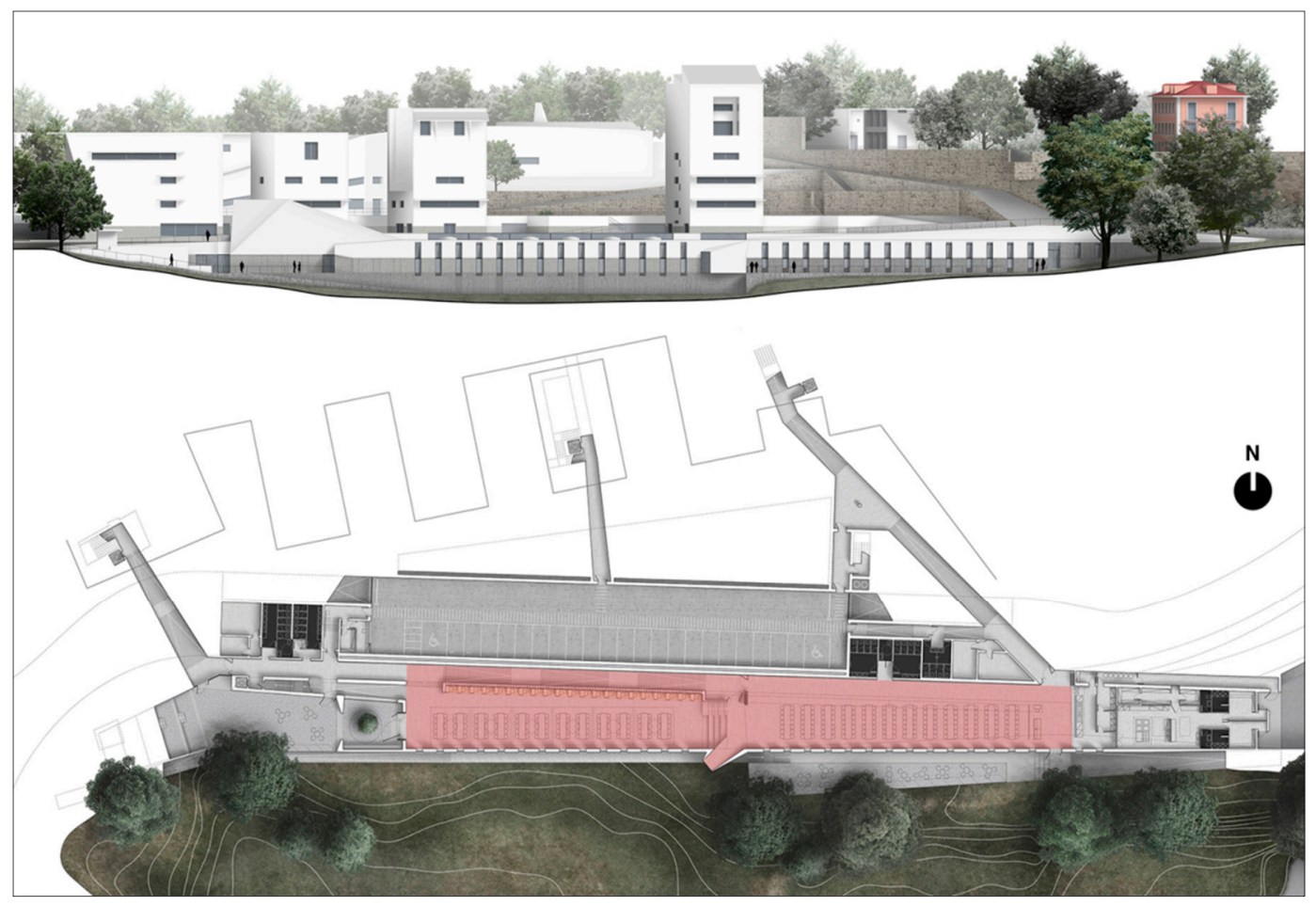

Figure 2. Building design: Main elevation and floor plan. 


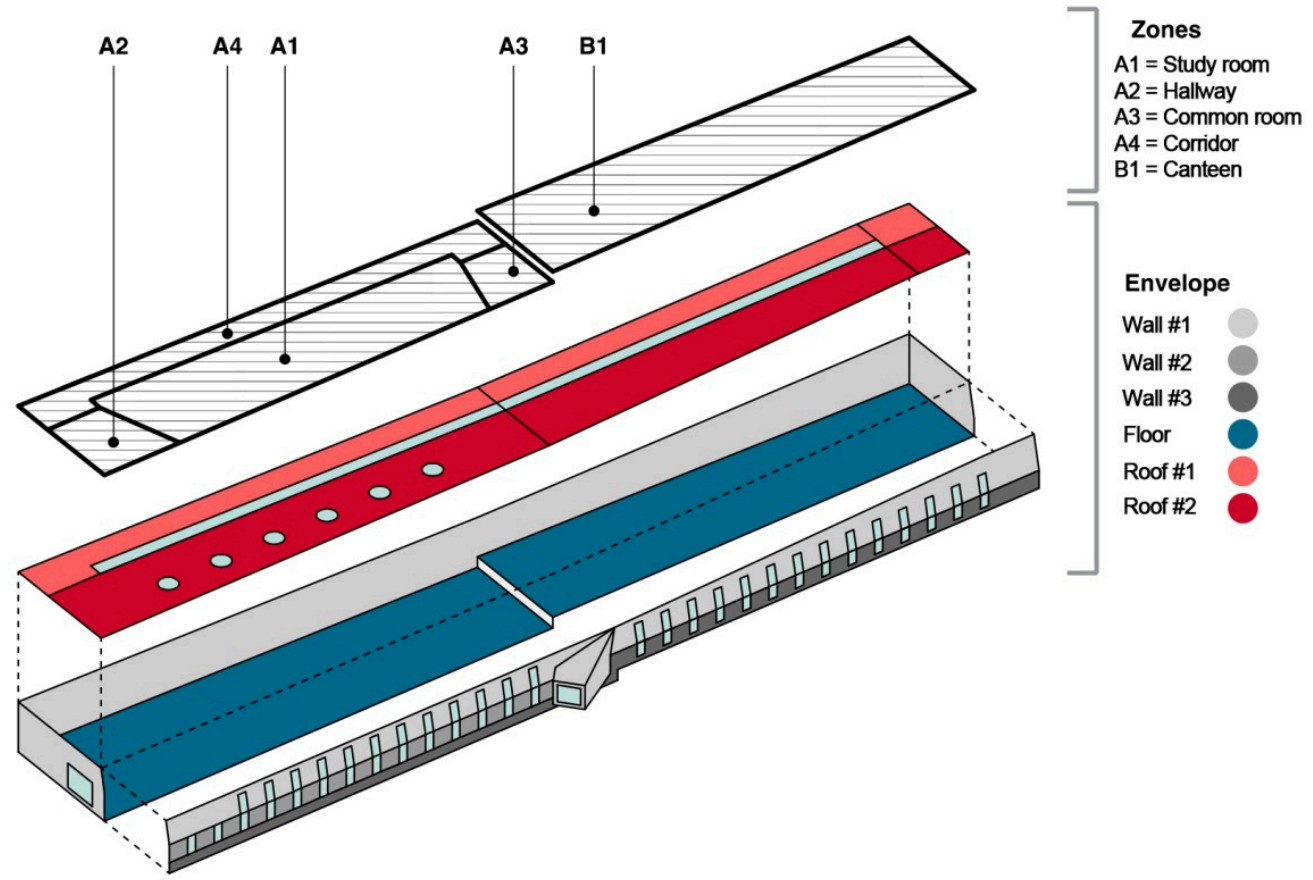

Figure 3. Building design: Thermal zones and envelope types.

Table 4. Envelope design: Layers.

\begin{tabular}{cl}
\hline Wall \#1 & Plaster $(2 \mathrm{~cm})$, Concrete $(26 \mathrm{~cm})$, Membrane + EPS $(15 \mathrm{~cm})$, Thermal-insulating Plaster $(2 \mathrm{~cm})$. \\
Wall \#2 & Plaster $(2 \mathrm{~cm})$, Concrete $(26 \mathrm{~cm})$, Membrane + EPS $(20 \mathrm{~cm})$, Granite Slab $(4 \mathrm{~cm})$. \\
Wall \#3 & Plaster $(2 \mathrm{~cm})$, Concrete $(26 \mathrm{~cm})$, Membrane + EPS $(12 \mathrm{~cm})$, Fair-faced Concrete Slab $(12 \mathrm{~cm})$. \\
Floor & Concrete Slab $(25 \mathrm{~cm})$, EPS $(15 \mathrm{~cm})$, Fair-faced Concrete Finishing $(10 \mathrm{~cm})$. \\
Roof \#1 & Concrete on Corrugated Steel $(8 \mathrm{~cm})$, Membrane + EPS $(14 \mathrm{~cm})$, Granite Blocks on Sand $(15 \mathrm{~cm})$. \\
Roof \#2 & Concrete on Corrugated Steel $(8 \mathrm{~cm})$, Membrane + EPS $(14 \mathrm{~cm})$, Green Roof $(20 \mathrm{~cm})$. \\
\hline Glazing & Low-e + Solar control Triple glazing $(4-15-6,8-15-4 \mathrm{~mm}$; Argon-filled Air gaps). \\
\hline Domes & Heat-stop external layer, Transparent middle layer, Translucent internal layer. \\
\hline
\end{tabular}

Table 5. Envelope design: Properties.

\begin{tabular}{|c|c|c|c|c|c|c|c|c|c|c|}
\hline & $\mathbf{U}$ & $\mathrm{U}_{\text {LIM }}$ & g & $\mathrm{g}_{\text {LIM }}$ & $\mathrm{Y}_{\mathrm{IE}}$ & $\mathrm{Y}_{\mathrm{IE}, \mathrm{LIM}}$ & $\sigma$ & $\sigma_{\text {LIM }}$ & $\tau$ & f \\
\hline & $\mathrm{W} / \mathrm{m}^{2} \mathrm{~K}$ & $\mathrm{~W} / \mathrm{m}^{2} \mathrm{~K}$ & & & $\mathrm{~W} / \mathrm{m}^{2} \mathrm{~K}$ & $W / \mathbf{m}^{2} \mathrm{~K}$ & $\mathrm{~kg} / \mathrm{m}^{2}$ & $\mathrm{~kg} / \mathrm{m}^{2}$ & h & - \\
\hline Wall \#1 & 0.16 & 0.30 & & & 0.016 & & 671.00 & & 11.03 & 0.099 \\
\hline Wall \#2 & 0.18 & 0.30 & & & 0.018 & & 771.40 & & 11.31 & 0.097 \\
\hline Wall \#3 & 0.25 & 0.30 & - & - & 0.024 & & 759.60 & & 11.50 & 0.092 \\
\hline Floor & 0.22 & 0.25 & - & - & / & 0.10 & 337.50 & 230 & / & / \\
\hline Roof \#1 & 0.18 & 0.25 & & & / & & 522.50 & & / & / \\
\hline Roof \#2 & 0.21 & 0.25 & & & / & & 823.00 & & / & / \\
\hline Glazing & 0.50 & 2.20 & 0.37 & 0.60 & & & - & & & \\
\hline Domes & 1.90 & 2.20 & 0.31 & 0.60 & & & - & & & \\
\hline
\end{tabular}

Note- $\mathrm{U}_{\text {LIM }}$ includes the effects of thermal bridges on the opaque envelope. $\mathrm{U}$ is the Stationary Thermal Transmittance. $\mathrm{g}$ is the Solar Factor. YIE is the Dynamic Thermal Transmittance. $\sigma$ is the Surface Mass. $\tau$ is the Time Shift and $f$ is the Attenuation Factor. 
Table 6. Building design: Reference values and data.

\begin{tabular}{|c|c|c|c|c|c|c|c|}
\hline $\begin{array}{l}\text { Building Data } \\
\text { Gross floor area } \\
\text { Analyzed floor area }\end{array}$ & $\begin{array}{l}\text { A FLOOR,TOT } \\
\text { A }_{\text {FLOOR }}\end{array}$ & $\begin{array}{l}\mathrm{m}^{2} \\
\mathrm{~m}^{2}\end{array}$ & $\begin{array}{l}4200 \\
1170\end{array}$ & $\begin{array}{l}\text { Vents area (Inlets) } \\
\text { Vents area (Outlets) } \\
\text { Vents area ratio }\end{array}$ & $\begin{array}{l}A_{V, I N} \\
A_{V, \text { OUT }} \\
A_{V, I N} / A_{V, \text { OUT }}\end{array}$ & $\begin{array}{l}\mathrm{m}^{2} \\
\mathrm{~m}^{2} \\
-\end{array}$ & $\begin{array}{l}12 \\
16 \\
0.75\end{array}$ \\
\hline Analyzed volume & V & $\mathrm{m}^{3}$ & 4700 & Opaque Envelope & & & \\
\hline External Surf. (total) & $\mathrm{A}_{\text {EXT,TOT }}$ & $\mathrm{m}^{2}$ & 3400 & Compactness (total) & $\mathrm{A}_{\mathrm{EXT}, \mathrm{TOT}} / \mathrm{V}$ & - & 0.72 \\
\hline External Surf. (air) & $\mathrm{A}_{\mathrm{EXT}, \mathrm{AIR}}$ & $\mathrm{m}^{2}$ & 1700 & Compactness (air) & $\mathrm{A}_{\mathrm{EXT}, \mathrm{AIR}} / \mathrm{V}$ & - & 0.36 \\
\hline South & $\mathrm{A}_{\mathrm{EXT}, \mathrm{S}}$ & $\mathrm{m}^{2}$ & 538 & Compactness (ground) & $\mathrm{A}_{\mathrm{EXT}, \mathrm{GRO} / \mathrm{V}}$ & - & 0.36 \\
\hline Roof & $\mathrm{A}_{\mathrm{EXT}, \mathrm{R}}$ & $\mathrm{m}^{2}$ & 1105 & Directional Shape Factor & & & \\
\hline West & $\mathrm{A}_{\mathrm{EXT}, \mathrm{W}}$ & $\mathrm{m}^{2}$ & 57 & North & $\mathrm{A}_{\mathrm{EXT}, \mathrm{N}} / \mathrm{A}_{\mathrm{EXT}, \mathrm{TOT}}$ & - & 0.14 \\
\hline External Surf. (ground) & $\mathrm{A}_{\text {EXT,GRO }}$ & $\mathrm{m}^{2}$ & 1700 & South & $\mathrm{A}_{\text {EXTS }} / \mathrm{A}_{\mathrm{EXTTOT}}$ & - & 0.16 \\
\hline North & $\mathrm{A}_{\mathrm{EXT}, \mathrm{N}}$ & $\mathrm{m}^{2}$ & 462 & Roof & $\mathrm{A}_{\text {EXT,R }} / \mathrm{A}_{\text {EXT,TOT }}$ & - & 0.32 \\
\hline East & $\mathrm{A}_{\mathrm{EXT}, \mathrm{E}}$ & $\mathrm{m}^{2}$ & 68 & Floor & $\mathrm{A}_{\mathrm{EXT}, \mathrm{F}} / \mathrm{A}_{\mathrm{EXT}, \mathrm{TOT}}$ & - & 0.34 \\
\hline Floor & $\mathrm{A}_{\mathrm{EXT}, \mathrm{F}}$ & $\mathrm{m}^{2}$ & 1170 & West & $\mathrm{A}_{\mathrm{EXT}, \mathrm{W}} / \mathrm{A}_{\mathrm{EXT}, \mathrm{TOT}}$ & - & 0.02 \\
\hline Ext. Ratio (air/ground) & $\mathrm{A}_{\mathrm{RAT}}$ & - & 0.50 & East & $\mathrm{A}_{\mathrm{EXT}, \mathrm{E}} / \mathrm{A}_{\mathrm{EXT}, \mathrm{TOT}}$ & - & 0.02 \\
\hline Glazing Surface & $\mathrm{A}_{\mathrm{GL}, \mathrm{TOT}}$ & $\mathrm{m}^{2}$ & 230 & Glazed Envelope & & & \\
\hline North & $\mathrm{A}_{\mathrm{GL}, \mathrm{N}}$ & $\mathrm{m}^{2}$ & 0 & Window/Wall ratio & $\mathrm{A}_{\mathrm{GL}, \mathrm{TOT}} / \mathrm{A}_{\mathrm{EXT}, \mathrm{TOT}}$ & - & 0.07 \\
\hline South & $A_{G L, S}$ & $\mathrm{~m}^{2}$ & 95 & Window/Ext. S. ratio & $\mathrm{A}_{\mathrm{GL}, \mathrm{TOT}} / \mathrm{A}_{\mathrm{EXT}, \mathrm{AIR}}$ & - & 0.13 \\
\hline Roof & $A_{G L, R}$ & $\mathrm{~m}^{2}$ & 120 & Window/Floor ratio & $\mathrm{A}_{\mathrm{GL}, \mathrm{TOT}} / \mathrm{A}_{\mathrm{FLOOR}}$ & - & 0.19 \\
\hline West & $\mathrm{A}_{\mathrm{GL}, \mathrm{W}}$ & $\mathrm{m}^{2}$ & 15 & Directional WWR & & & \\
\hline East & $A_{G L, E}$ & $\mathrm{~m}^{2}$ & 0 & North & $\mathrm{A}_{\mathrm{GL}, \mathrm{N}} / \mathrm{A}_{\mathrm{EXT}, \mathrm{N}}$ & - & 0.14 \\
\hline Length (approx.) & $\mathrm{L}$ & $\mathrm{m}$ & 111 & South & $\mathrm{A}_{\mathrm{GL}, \mathrm{S}} / \mathrm{A}_{\mathrm{EXT}, \mathrm{S}}$ & - & 0.17 \\
\hline Depth (approx.) & $\mathrm{D}$ & $\mathrm{m}$ & 12 & Roof & $\mathrm{A}_{\mathrm{GL}, \mathrm{R}} / \mathrm{A}_{\mathrm{EXT}, \mathrm{R}}$ & - & 0.11 \\
\hline Building Ratio & $\mathrm{L} / \mathrm{D}$ & - & 9.25 & West & $\mathrm{A}_{\mathrm{GL}, \mathrm{W}} / \mathrm{A}_{\mathrm{EXT}, \mathrm{W}}$ & - & 0.26 \\
\hline Thermal Mass & A MASS & $\mathrm{m}^{2}$ & 1782 & East & $\mathrm{A}_{\mathrm{GL}, \mathrm{E}} / \mathrm{A}_{\mathrm{EXT}, \mathrm{E}}$ & - & 0.02 \\
\hline Daylight Factor & & & & Glazing ratio & & & \\
\hline A1 & $\mathrm{DF}_{\mathrm{A} 1}$ & $\%$ & 4.10 & North & $\mathrm{A}_{\mathrm{GL}, \mathrm{N}} / \mathrm{A}_{\mathrm{GL}, \mathrm{TOT}}$ & - & 0.00 \\
\hline A2 & $\mathrm{DF}_{\mathrm{A} 2}$ & $\%$ & 1.75 & South & $\mathrm{A}_{\mathrm{GL}, \mathrm{S}} / \mathrm{A}_{\mathrm{GL}, \mathrm{TOT}}$ & - & 0.41 \\
\hline A3 & $\mathrm{DF}_{\mathrm{A} 3}$ & $\%$ & 1.90 & Roof & $\mathrm{A}_{\mathrm{GL}, \mathrm{R}} / \mathrm{A}_{\mathrm{GL}, \mathrm{TOT}}$ & - & 0.52 \\
\hline A4 & $\mathrm{DF}_{\mathrm{A} 4}$ & $\%$ & 3.25 & West & $\mathrm{A}_{\mathrm{GL}, \mathrm{W}} / \mathrm{A}_{\mathrm{GL}, \mathrm{TOT}}$ & - & 0.07 \\
\hline B1 & $\mathrm{DF}_{\mathrm{B} 1}$ & $\%$ & 3.30 & East & $\mathrm{A}_{\mathrm{GL}, \mathrm{E}} / \mathrm{A}_{\mathrm{GL}, \mathrm{TOT}}$ & - & 0.00 \\
\hline
\end{tabular}

\section{Energy Simulations Aimed at Climate Responsive Design}

\subsection{Descriptions of the Simulation Scenarios}

Context-related guidelines and rules of thumb, reported in literature, have guided the design process of the building presented in the previous section. In this next part, the energy simulation tool allows the optimization and fine-tuning process of the operation schedules and set-points of those components (such as solar shading, operable vents and dimmable lights) which have been embedded with BACS. Energy simulation tools were developed more than thirty years ago and have been perfected ever since. A slightly outdated study, led by Crawley et al. [58] back in 2005, compares some of the best programs at that moment in time, although concluding that none is considerably better than the others; it is therefore suggested to use several tools at once and to cross-check the results for improved accuracy. Nevertheless, energy simulation is used today in the research field mostly, and just barely by professionals, although the EU has recently supported its further adoption thanks to both the EN 52016-1 regulation (Energy Performance of Buildings-Energy needs for heating and cooling, internal temperatures and latent heat loads-Part 1: Calculation procedures) and the EN 52017-1 regulation (Energy Performance of Buildings-Sensible and latent heat loads and internal temperatures-Part 1: Generic calculation procedures), which update the hourly calculation procedures of the old EN 13790 and EN 13791. In this case study, energy simulation is structured according to Scenarios; starting from the reference building "as designed" (Scenario 1), BACS devices are added one at a time (Scenarios $2 \div 4$ ) until the aforementioned goals are met. 


\section{Scenario}

- Scenario 1-Baseline Building

- Scenario 2-Solar Shading

- Scenario 3-Natural Ventilation

- Scenario 4-Daylight Control

- Scenario 5-Enhanced
Automated Component Strategies

Solar shades

Operable vents

Light Controls

All
Passive Solar, Daylighting

Natural Ventilation

Daylighting, Energy Efficiency

All

In each Scenario, set-points and schedules are varied within a reasonable range, until improvements in terms of comfort and energy use are achieved, whereas weather data and internal loads are assumed to be invariables. The assessment is based on either thermal comfort or heat balance. All simulations cover a whole reference year, extended of a whole month of warm-up time; further analyses will concentrate on the hourly behavior during selected typical weeks.

\subsection{Inputs and References}

\subsubsection{Climate Data}

Energy simulations are based on hourly weather datasets, namely a spreadsheet made up of 8760 entries; to help designers, institutions have come up with several types of reference years, artificially assembled starting from measurements taken throughout many decades.

The most common dataset types are TRY (Test Reference Year), TMY (Test Meteorological Year) and IWEC (International Weather for Energy Calculation). Reference years can also be created following the procedure illustrated in the ISO EN 15927-4/2005 regulation (hygrothermal performance of buildings-calculation and presentation of climatic data-Part 4; hourly data for assessing the annual energy use for heating and cooling). This case-study uses the IWEC dataset for the Porto Airport's weather station (Pedras Rubras) provided by ASHRAE.

\subsubsection{Internal Gains}

Internal heat gains are caused, at least in buildings such as homes and offices, by occupancy, electronic devices, equipment, and luminaires. As far as the last three categories are concerned, the sensible heat loads are directly proportional to the nominal power and are normally reported as values per floor area unit $\left(\mathrm{W} / \mathrm{m}^{2}\right)$.

Occupants produce both sensible and latent heat (moisture), both depending on the degree of physical activity and on the amount of clothing he is wearing. Metabolic rate increases with physical activity and is measured in "met" ( 1 met equals to $58 \mathrm{~W} / \mathrm{m}^{2}$ of body surface, a person averaging around $1.5 \mathrm{~m}^{2}$ ); to quiet activities, such as those carried out in the case-study building, correspond around 1.2 to 1.3 met. Occupancy, lighting, and use of devices, variable throughout the day, are therefore quantified by means of schedules, as in Figure 4, and peak loads per floor area unit, as in Table 7. 

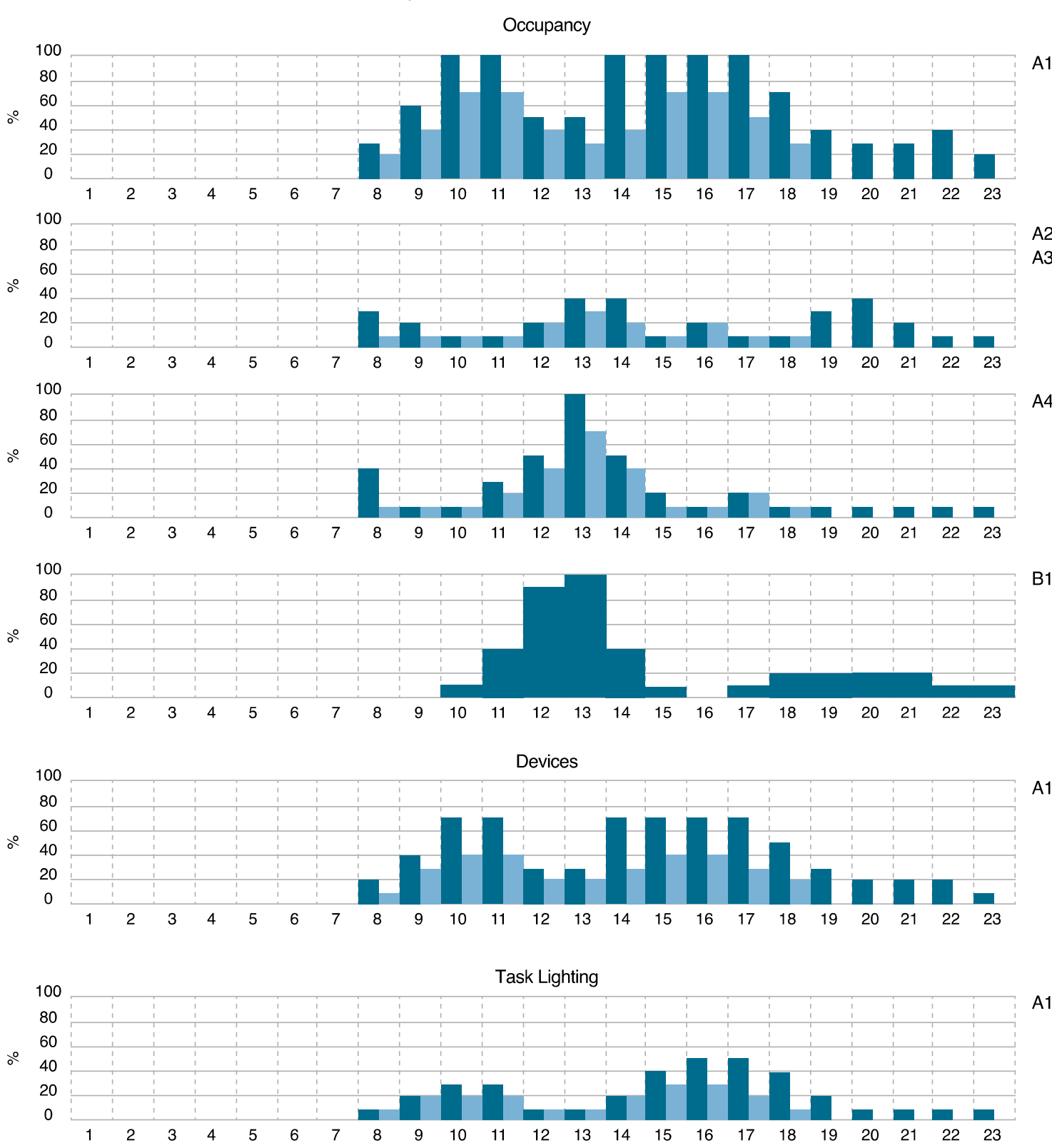

Figure 4. Schedules: Occupancy, devices and task lighting (The ID on the right of each chart refers to the thermal zone, as in the following table. Ambient Lighting in both A and B thermal zones is automatically controlled based on daylight availability; it is therefore not included in schedules. Task Lighting is manually controlled and follows, albeit loosely, the occupancy patterns).

Table 7. Internal gains: Occupancy, devices, and lighting.

\begin{tabular}{cccccccc}
\hline \multirow{2}{*}{ ID } & & \multicolumn{2}{c}{ Occupancy } & Surface & Devices & Ambient Lighting & Task Lighting \\
\cline { 3 - 8 } & & $\mathbf{n}^{\circ}$ & $\mathbf{W} / \mathbf{p e r s}$ & $\mathbf{m}^{\mathbf{2}}$ & $\mathbf{W} / \mathbf{m}^{\mathbf{2}}$ & $\mathbf{W} / \mathbf{m}^{\mathbf{2}}$ & $\mathbf{W} / \mathbf{m}^{\mathbf{2}}$ \\
\hline A1 & Study room & 110 & 100 & 370 & 2.00 & 4.5 & 9.0 \\
A2 & Hallway & 5 & 110 & 56 & - & 2.5 & - \\
A3 & Common room & 10 & 150 & 56 & - & 5.0 & - \\
A4 & Corridor & 5 & 140 & 166 & - & 3.5 & - \\
B1 & Canteen & 240 & 110 & 521 & - & 8.0 & - \\
\hline
\end{tabular}




\subsubsection{Comfort Model}

Thermal comfort, otherwise described as a feeling of "satisfaction with the thermal environment" [59], is a complex phenomenon, based on quantitative and qualitative factors and usually correlated with other forms of comfort such as acoustic and visual quality of the indoor spaces.

Concerning educational buildings, it is well known that students spent much of their time in schools, thus it is important to provide a good thermal comfort. The thermal environment is particularly important because it is closely related to pupils' health and performance [60]. In facts, poor thermal environments, produce thermal discomfort, and may affect a pupils learning process [60-63].

Today's regulations, such as the ISO 7730/2005 (Ergonomics of the thermal environment-Analytical determination and interpretation of thermal comfort using calculation of the PMV and PPD indices and local thermal comfort criteria) and the EN 15251/2007 (indoor environmental input parameters for design and assessment of energy performance of buildings addressing indoor air quality, thermal environment, lighting, and acoustics) take into account two of the most important comfort models: The Fanger model and the Adaptive Comfort model [50,59].

The former sees occupants as passive recipients of given environmental conditions; it becomes less accurate as temperature increases or decreases considerably, being suitable for mechanically conditioned buildings only. The latter assumes that occupants will actively engage in physical, behavioral, and psychological adjustments; as such, it works better in free-running buildings, and is, on this account, adopted in this study. As reported in Table 8, the EN 15251/2007 indicates a proportion between the comfort range $\left(\mathrm{T}_{\mathrm{COMF}, \mathrm{MAX}} / \mathrm{T}_{\mathrm{COMF}, \mathrm{MIN}}\right)$ and the outdoor running mean temperature $\left(\mathrm{T}_{\mathrm{RM}}\right)$, where the latter may be written with Equation (1):

$$
\mathrm{T}_{\mathrm{RM}}=\left[(1-\mathrm{a}) \cdot \mathrm{T}_{\mathrm{ED}-1}\right]+\left(\mathrm{a} \cdot \mathrm{T}_{\mathrm{RM}-1}\right)
$$

In Equation (1), $\mathrm{T}_{\mathrm{ED}-1}$ is the dry-bulb temperature of a previous time interval (i.e., hours, days, weeks), $\mathrm{T}_{\mathrm{RM}-1}$ is the outdoor running mean temperature of the previous interval, and " $\mathrm{a}$ " is the half-life coefficient, which usually equals 0.8 and weighs the effects of occupant's expectations and time shift. $\mathrm{T}_{\mathrm{DIFF}}$ is a tolerance, varying according to the building Category (Table 9); in this case-study, Category II is chosen.

Table 8. Adaptive thermal comfort: Temperature range.

\begin{tabular}{lccc}
\hline $\mathrm{T}_{\mathbf{R M}}$ & $<\mathbf{1 0}{ }^{\circ} \mathrm{C}$ & $\mathbf{1 0} \div \mathbf{3 0}{ }^{\circ} \mathrm{C}$ & $>30^{\circ} \mathrm{C}$ \\
$\mathrm{T}_{\mathrm{COMF}, \mathrm{CAX}}$ & $24{ }^{\circ} \mathrm{C}$ & $0.33 \cdot \mathrm{T}_{\mathrm{RM}}+18+\mathrm{T}_{\mathrm{DIFF}}$ & $26{ }^{\circ} \mathrm{C}$ \\
\hline $\mathrm{T}_{\mathbf{R M}}$ & $<\mathbf{1 0}{ }^{\circ} \mathrm{C}$ & $\mathbf{1 0} \div \mathbf{3 0}{ }^{\circ} \mathrm{C}$ & $/$ \\
$\mathrm{T}_{\mathrm{COMF}, M I N}$ & $20{ }^{\circ} \mathrm{C}$ & $0.33 \cdot \mathrm{T}_{\mathrm{RM}}+18-\mathrm{T}_{\text {DIFF }}$ & \\
\hline \multicolumn{4}{c}{ Note-All values are valid for free-running buildings only. }
\end{tabular}

Table 9. Adaptive thermal comfort: Building categories.

\begin{tabular}{cccc}
\hline \multirow{2}{*}{ Category } & Description & PPD & T $_{\text {DIFF }}$ \\
\cline { 3 - 4 } & & $\mathbf{\%}$ & ${ }^{\circ} \mathbf{C}$ \\
\hline I & Special requirements & $\leq 6$ & 2 \\
II & New buildings & $\leq 10$ & 3 \\
III & Existing buildings & $\leq 15$ & 4 \\
IV & Intolerable & $\geq 15$ & - \\
\hline
\end{tabular}

Note-PPD (Predicted Percentage of Dissatisfied) accounts for the inevitable percentage of occupants that will be dissatisfied with the thermal conditions.

The resulting comfort range is superimposed as a grey-colored stripe in each of the following temperature charts. For indoor conditions to be deemed comfortable, the indoor operative temperature 
$\left(\mathrm{T}_{\mathrm{OP}}\right)$ must fall within the comfort range. $\mathrm{T}_{\mathrm{OP}}$ accounts for both conductive and radiative heat transfer, and may in general be expressed with Equation (2):

$$
\mathrm{T}_{\mathrm{OP}}=\left(\mathrm{h}_{\mathrm{R}} \cdot \mathrm{T}_{\mathrm{MR}}+\mathrm{h}_{\mathrm{C}} \cdot \mathrm{T}_{\mathrm{AIR}}\right) /\left(\mathrm{h}_{\mathrm{R}}+\mathrm{h}_{\mathrm{C}}\right)
$$

where $T_{M R}$ is the Mean Radiant Temperature, $T_{A I R}$ is the Indoor Air Temperature, and $h_{R}$ and $h_{C}$ are respectively the radiant and convective heat transfer coefficients. When the air speed is below $0.1 \mathrm{~m} / \mathrm{s}$ and the metabolic rate is between 1.0 and 1.3, $\mathrm{T}_{\mathrm{OP}}$ may be rewritten with Equation (3):

$$
\mathrm{T}_{\mathrm{OP}}=\left(\mathrm{T}_{\mathrm{MR}}+\mathrm{T}_{\mathrm{AIR}}\right) / 2
$$

\section{Results and Discussion}

In this Subsection, BACS are introduced one at a time in order to control the activation schedules, the set-points and operations of those building components, whose features directly influence the global building behavior.

From here onwards, the analysis are only focused on the most significant and yet critical thermal zone; the study room (A1). As already stated, simulations are assessed considering the indoor operative temperature profiles (compared to thermal comfort range) and the main heat losses and gains. In detail, the indoor operative temperature profiles are calculated using daily averaged values obtained from the hourly step based simulations. The operative temperature profiles are referred to free run conditions, taking into account only the BACS considered for each Scenario. When the operative temperature falls outside the thermal comfort range, the HVAC systems considered turned on and the related energy consumptions were computed.

\subsection{Scenario 1-Baseline}

The Baseline scenario represents the reference building as designed (see previous Section), according to the bioclimatic guidelines and rules of thumb found in literature [23,29] and devoid of any kind of automation device. Figure 5 shows the daily mean indoor operative temperature profile, together with the main heat losses and gains; in the first chart, the temperature rises up to $35^{\circ} \mathrm{C}$ and stays above the comfort range even during winter. The main sources of excess heat are irradiation (through glazing), occupancy and lighting. This first evaluation serves as the basis for the following Scenarios: Automated solar shades are introduced in Scenario 2, automated operable vents (Scenario 3), and daylight-dependent dimmable light controls (Scenario 4).

\subsection{Scenario 2-Solar Shading}

Solar shading is one of the simplest and yet most effective strategies for minimizing overheating and keeping temperatures within the comfortable range. In this case-study building, windows and skylights were fitted, outside and inside respectively, with automated roller shades, whose transmission coefficient is set to $30 \%$. Shades are operative from April through September, according to the schedule contained in Table 10a,b; their activation, though, is based on either air temperature or incident solar radiation.

Four set-points were chosen for solar radiation (100-200-300-400 W/ $\mathrm{m}^{2}$, although only the first and last are shown in the charts) and two for air temperature $\left(\mathrm{T}_{\mathrm{IN}}=26^{\circ} \mathrm{C} ; \mathrm{T}_{\mathrm{OUT}}=20^{\circ} \mathrm{C}\right)$. Both systems achieve positive results in terms of daily mean indoor operative temperatures (as in Figures $6 \mathrm{a}$ and $7 \mathrm{a}$ ) thereby improving indoor comfort conditions. However, as regards the heat transmission, and solar gains in particular (Figures $6 \mathrm{~b}$ and $7 \mathrm{~b}$ ) temperature-based control does not guarantee as steady a result as radiation-based control. In light of this, radiation-based control will be employed for solar shading from here onwards. 
a)

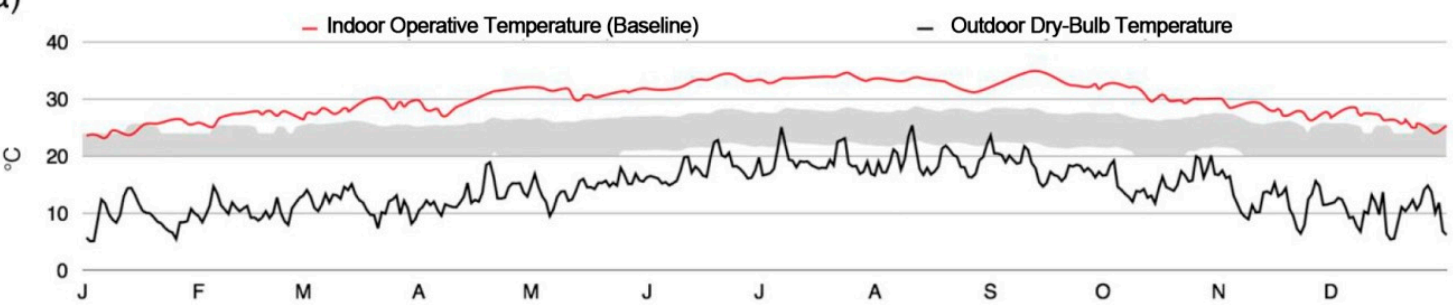

b)

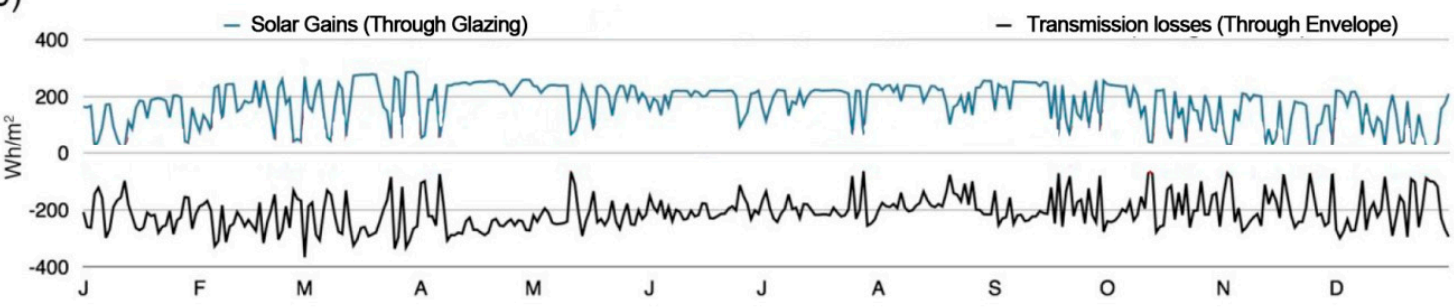

c)

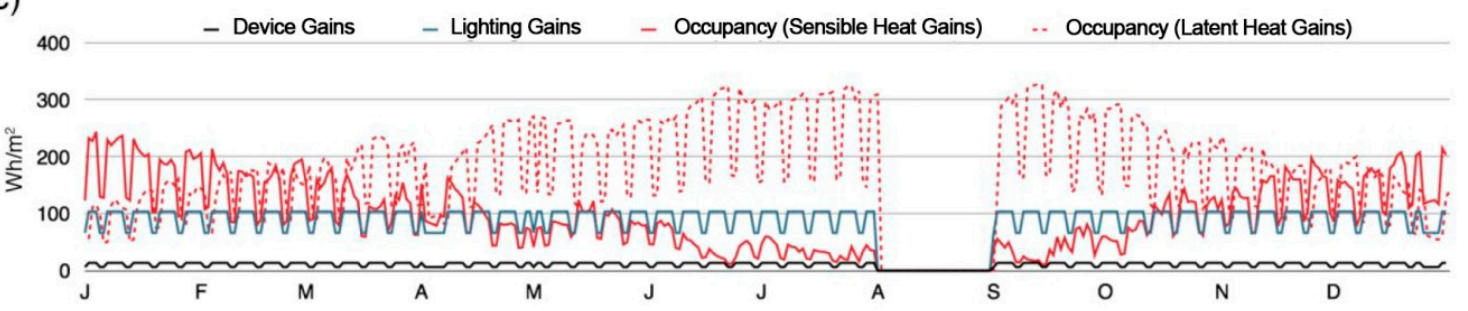

Figure 5. Scenario 1: Baseline: (a) Temperature profiles; (b) external heat losses and gains; and (c) internal heat gains.

Table 10. Scenario $2 \div 4$ : Schedules.

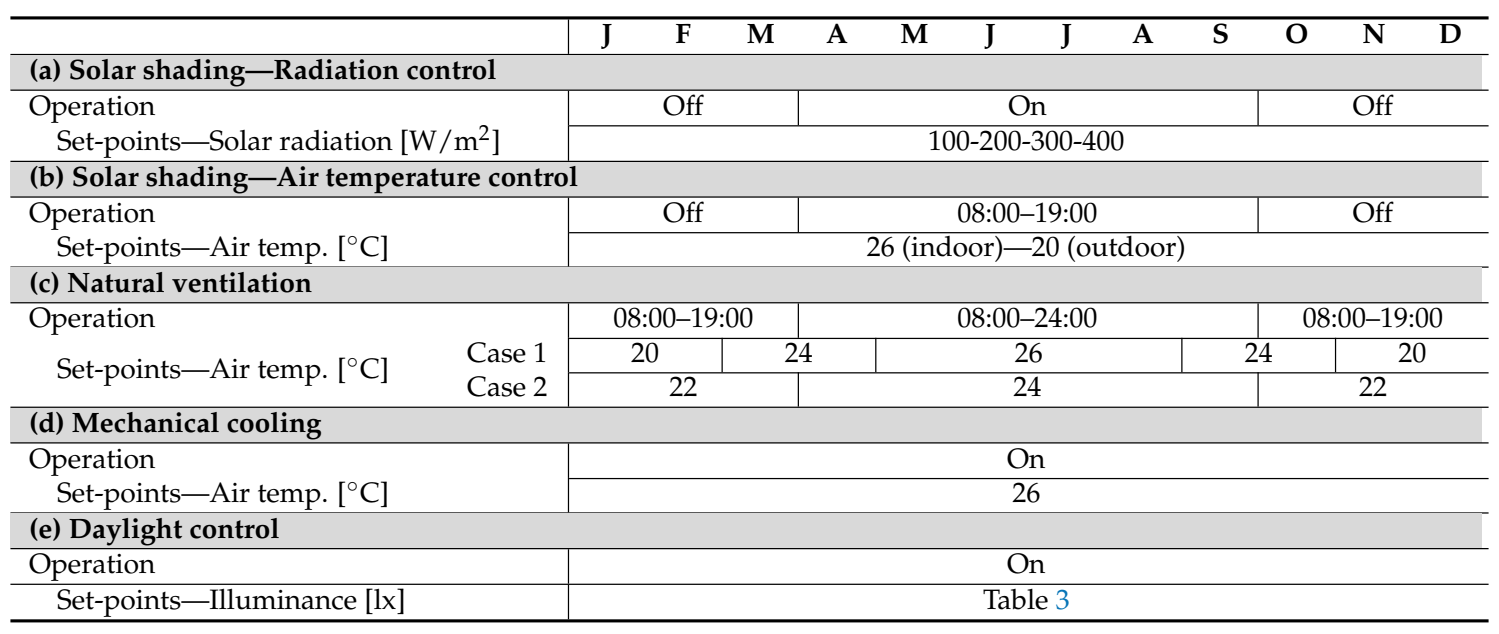


a)

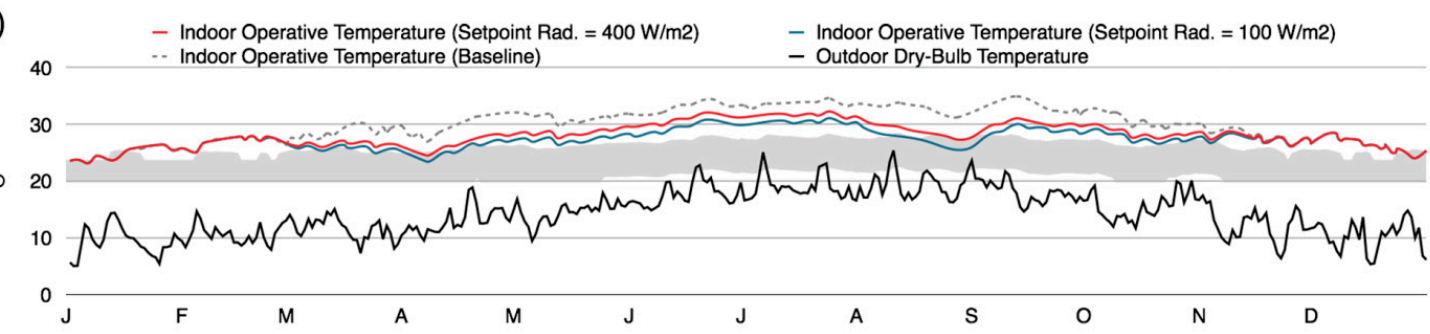

b)

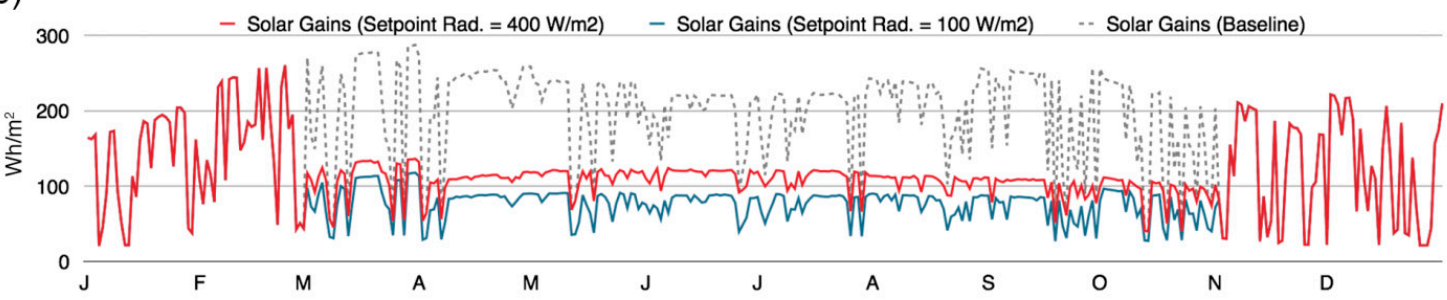

Figure 6. Scenario 2: Solar Shading (Radiation-based): (a) Temperature profiles; and (b) solar gains.

a)

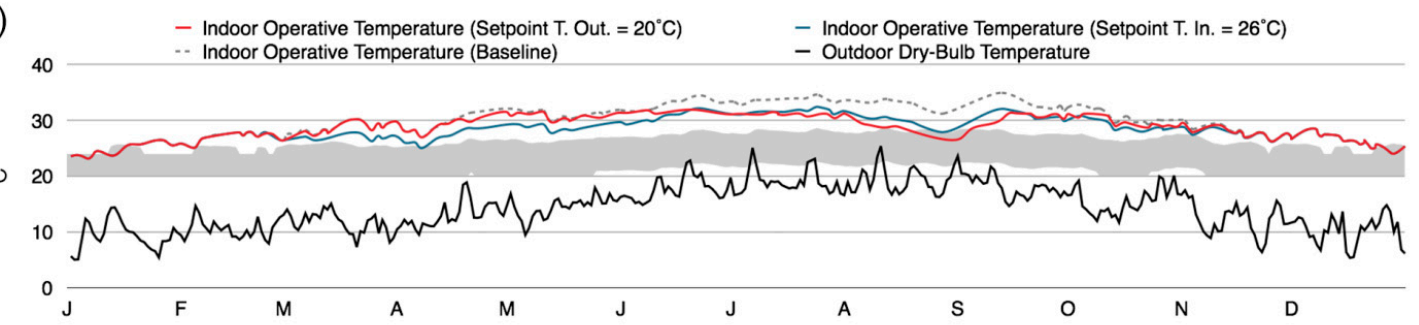

b)

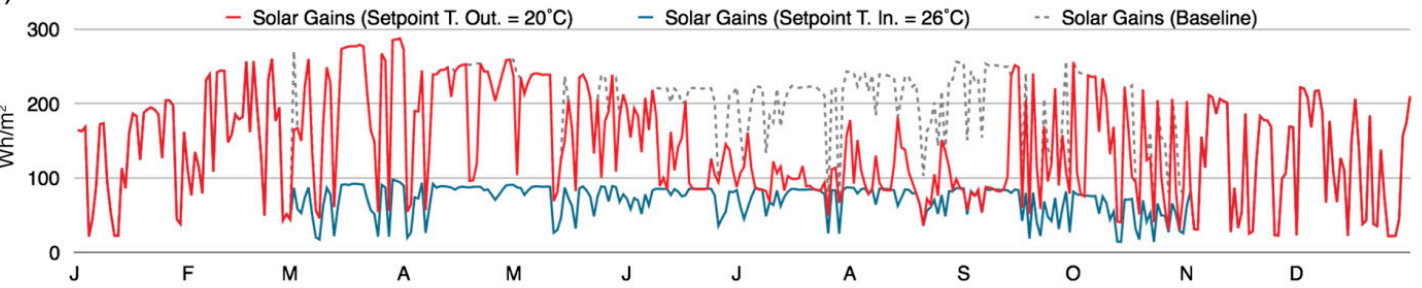

Figure 7. Scenario 2: Solar Shading (Temperature-based): (a) Temperature profiles; and (b) solar gains.

\subsection{Scenario 3-Natural Ventilation}

As pointed out by Olgyay [23], ventilation extends the comfort range upwards, favoring transpiration and therefore the human body's ability to withstand humidity. EnergyPlus breaks this complex phenomenon down into a system of nodes, constraints and paths, otherwise referred to as the "Airflow Network Model". In the case-study building, operable vents were placed on the Northern and Southern sides of the building. While they are operative all year-round (during selected time-slots, as in Table 10c), their actual use depends on indoor air temperature set-points (Case 1 and Case 2). An additional infiltration rate, inevitably caused by porosity, cracks and poor joinery, is set by default on $10^{-3} \div 10^{-5} \mathrm{~kg} /(\mathrm{m} \cdot \mathrm{s} \cdot \mathrm{Pa})$, depending on the envelope component. In a cool and windy climate, such as that of Porto, the effect of natural ventilation is truly remarkable; the daily mean indoor operative temperature is lowered into the comfort range (Figure 8a), while latent occupations gains are consistently reduced (Figure $8 \mathrm{~b}$ ), as opposed to the first scenario (Figure $5 \mathrm{c}$ ). If natural ventilation were unable to productively cool the building below $26^{\circ} \mathrm{C}$ (when the outdoor temperature, for instance, is higher than indoors, or there is simply not enough wind), an air conditioning system will step in. 


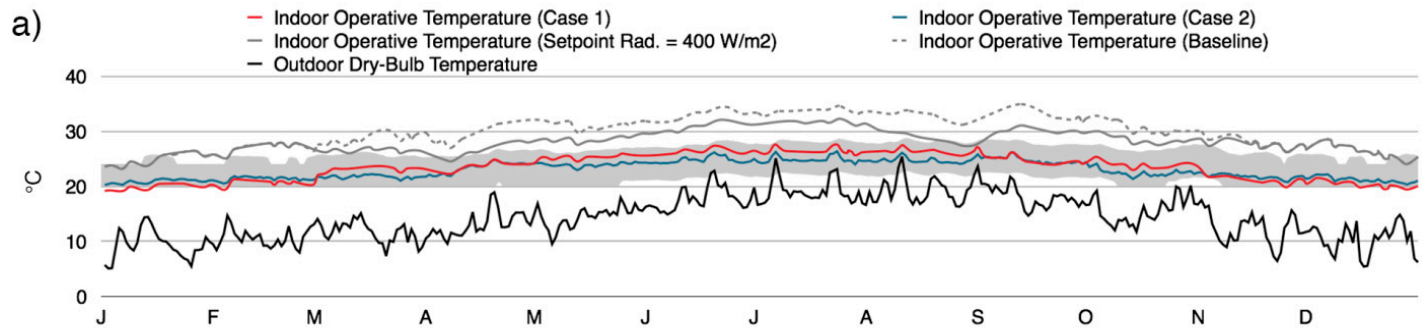

b)

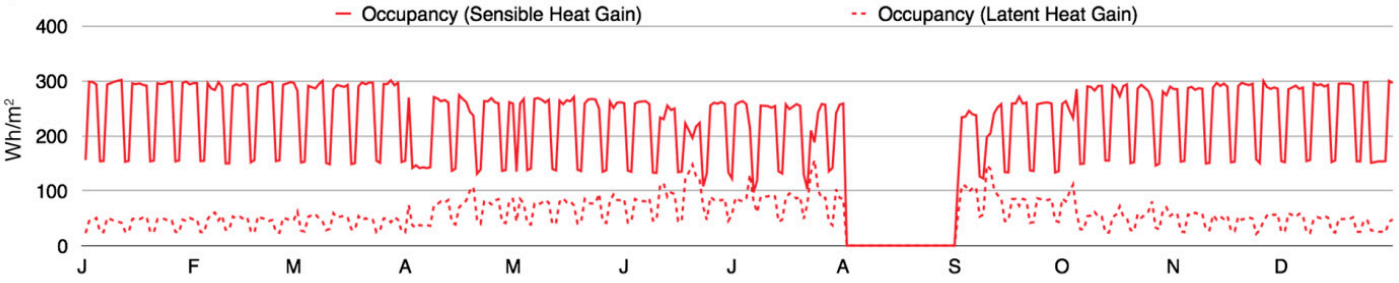

Figure 8. Scenario 3: Natural Ventilation: (a) Temperature profiles; and (b) occupancy gains.

\subsection{Scenario 4-Daylight Control}

Daylighting is inevitably related to architectural design, as windows must be sized and placed in such a way as to avoid direct sunlight, over-lighting, and glare; if well implemented, it reduces lighting loads and therefore energy use. BACS regulate the power supplied to the lights according to variations in the availability of daylight (illuminance measured on selected work planes) during the course of the year. Figure 9 compares the lighting gains of the case-study building when Daylight Control is enabled or disabled respectively; the result is obviously achieved in summer, when daylight is available all throughout the day.

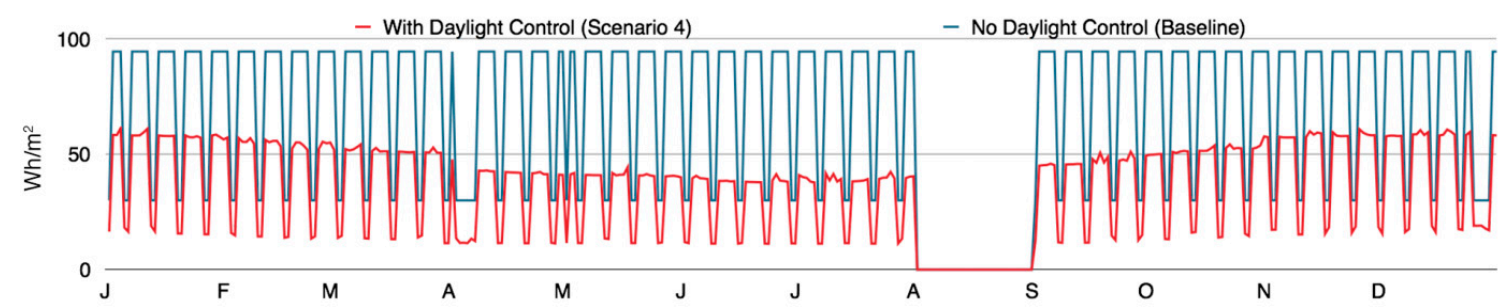

Figure 9. Scenario 4: Daylight Control. Lighting Gains.

\subsection{Scenario 5-Enhanced}

The final Scenario is nothing but a summary of the previous ones, as it brings all the individual strategies together into an integrated design; actual set-points are reported in Table 11. According to Figure 10a, which compares both the first and last Scenario, positive results were achieved in terms of daily mean temperature profiles. Figure 10b displays an overall energy balance for the whole reference year.

Table 11. Scenario $2 \div 4$ : Selected set points.

\begin{tabular}{ccccc}
\hline \multirow{2}{*}{ Strategy } & & \multicolumn{3}{c}{ Thermal Zones } \\
\cline { 3 - 5 } & & A1/A2/A3 & A4 & B1 \\
\hline Solar Shading & $\mathrm{W} / \mathrm{m}^{2}$ & 100 & $\mathrm{X}$ & 400 \\
Natural Vent. & ${ }^{\circ} \mathrm{C}$ & $22 / 24$ & $\mathrm{X}$ & $22 / 24$ \\
Mech. Cooling & ${ }^{\circ} \mathrm{C}$ & 26 & 26 & 26 \\
Daylight Control & - & $\mathrm{V}$ & $\mathrm{V}$ & $\mathrm{V}$ \\
Infiltrations & - & $\mathrm{V}$ & $\mathrm{V}$ & $\mathrm{V}$ \\
\hline
\end{tabular}

Note: " $\mathrm{V}$ " and " $\mathrm{X}$ " are used for a strategy which does not present set-points of schedules, and indicate, respectively, whether it has been adopted or not. 
a)

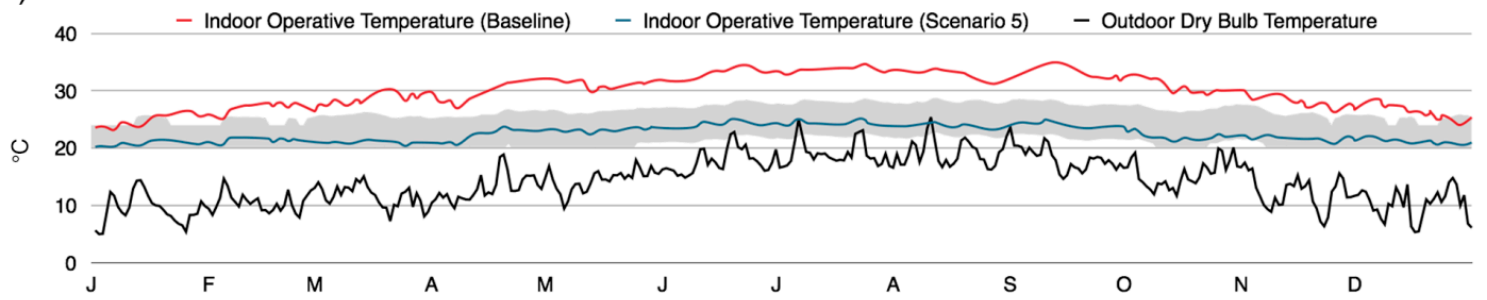

b)

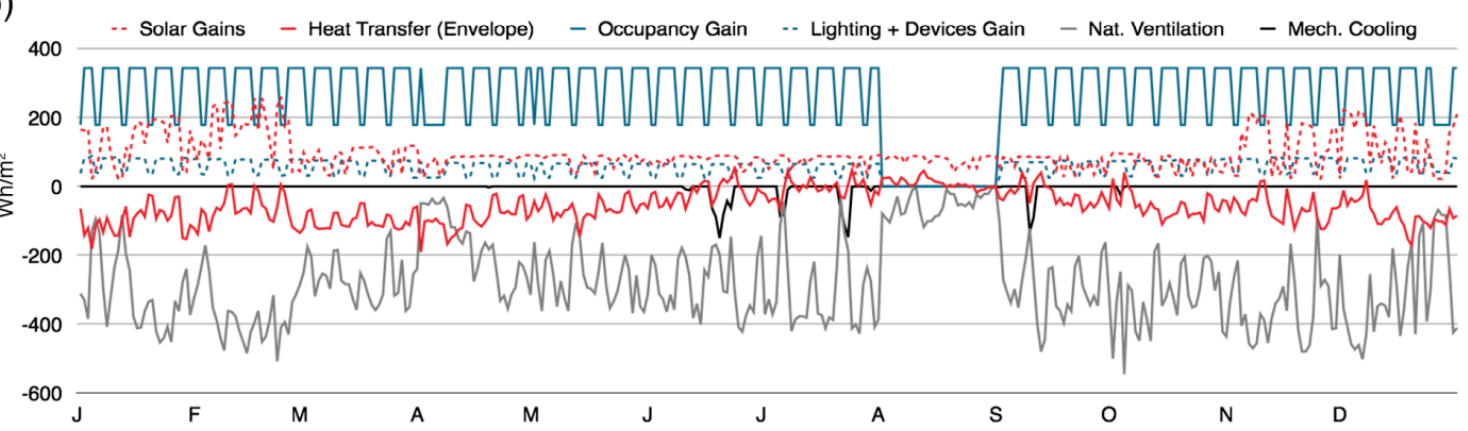

Figure 10. Scenario 5: Enhanced: (a) Temperature profiles; and (b) overall heat balance.

The hourly temperature profile and energy balance for selected typical weeks are previously shown. Energy simulations also ascertained that, based on an opening time of $4800 \mathrm{~h}$ on a yearly total of 8760, the Enhanced Scenario conforms to the Adaptive comfort model for more than $98 \%$ of the time; by comparison, the Baseline Scenario was found to comply only in $5 \%$ of the same time frame. Energy end-use calculations did not linger on less relevant shares such as domestic hot water (DHW), outdoor lighting and emergency lighting, but focused on plug loads (devices, such as laptops), indoor lighting, HVAC and BACS. All things considered, the overall reduction in electrical energy end-use between the Baseline Scenario and the Enhanced Scenario, was estimated to be around $53 \%$, as in Table 12. Unfortunately, both the annual energy end-use of Porto School of Architecture's existing premises and the average annual specific energy use of buildings of the same type and size in this region of Portugal were not available to the authors. As a comparison, an Italian study by ENEA (the Authority for Energy, Environment and New Technologies) [64] estimated the annual primary and final energy use in public schools and offices across Italy. Its authors acknowledge that potential savings in electrical energy up to $23 \%$ could be achieved thanks to renovations.

Table 12. Energy end-use calculations in the five Scenarios.

\begin{tabular}{|c|c|c|c|c|c|c|}
\hline & \multirow{2}{*}{ Scenario } & \multirow{2}{*}{$\begin{array}{l}\text { Average Operative } \\
\text { Temperature }\left({ }^{\circ} \mathrm{C}\right)\end{array}$} & \multicolumn{4}{|c|}{ Energy Use $\left(\mathrm{kWh} / \mathrm{m}^{2} \cdot\right.$ year $)$} \\
\hline & & & Lighting & HVAC & BACS & Total \\
\hline 1 & Baseline & 30.1 & 24.9 & 8.2 & 0.0 & 34.3 \\
\hline \multirow{2}{*}{2} & Solar Shading_radiation based & 28.8 & 26.2 & 3.5 & 0.6 & 30.3 \\
\hline & Solar Shading_temperature based & 29.3 & 25.9 & 3.9 & 0.6 & 30.4 \\
\hline 3 & Natural ventilation & 24.8 & 24.9 & 5.1 & 0.6 & 30.6 \\
\hline 4 & Daylight control & 29.5 & 11.4 & 8.0 & 0.6 & 20.0 \\
\hline 5 & Enhanced & 22.4 & 12.7 & 0.2 & 1.8 & 15.9 \\
\hline
\end{tabular}

\subsection{Hourly Breakdown}

A more detailed analysis examines the results on a daily basis, focusing on two typical weeks; from the 15th to the 21st of January and from the 22nd to the 28th of July. Only such an in-depth examination can detect the temperature swings over the course of a day and correlate the phenomenon to changes in energy balance. As expected, both in summer and winter-time (" $a$ " and "b", respectively, 
in each of the following charts), the hourly indoor operative temperature always falls within the predetermined comfort range (Figure 11).

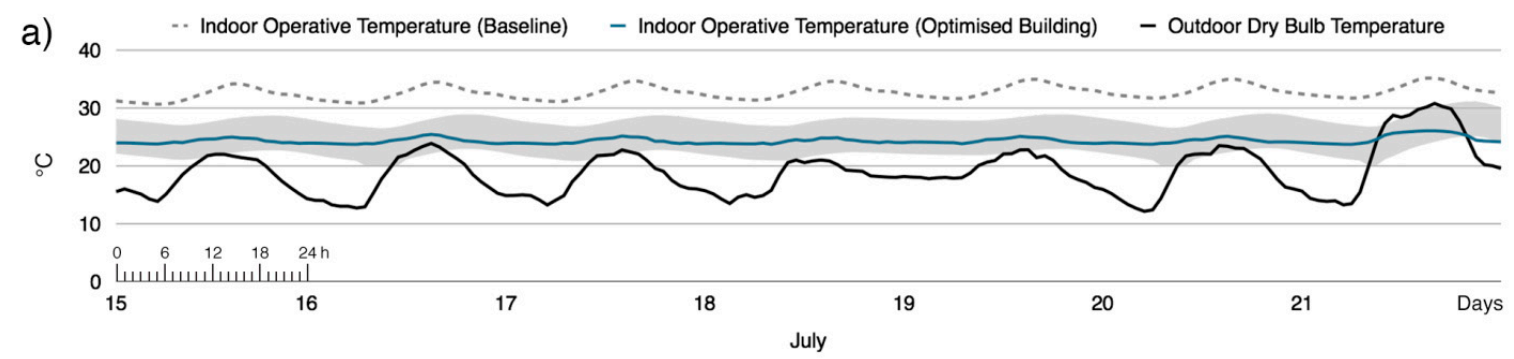

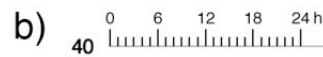

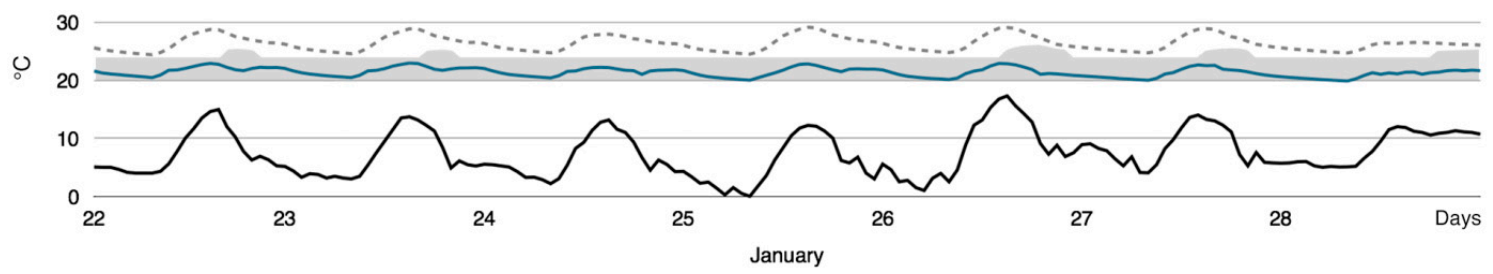

Figure 11. Scenario 5: Enhanced. Hourly Temperatures: (a) July; and (b) January.

In Figure 12, the hourly energy balance confirms a reduction of both the internal and envelope (external) gains; the quite large heat gain caused by occupation is, instead, counterbalanced by natural ventilation.
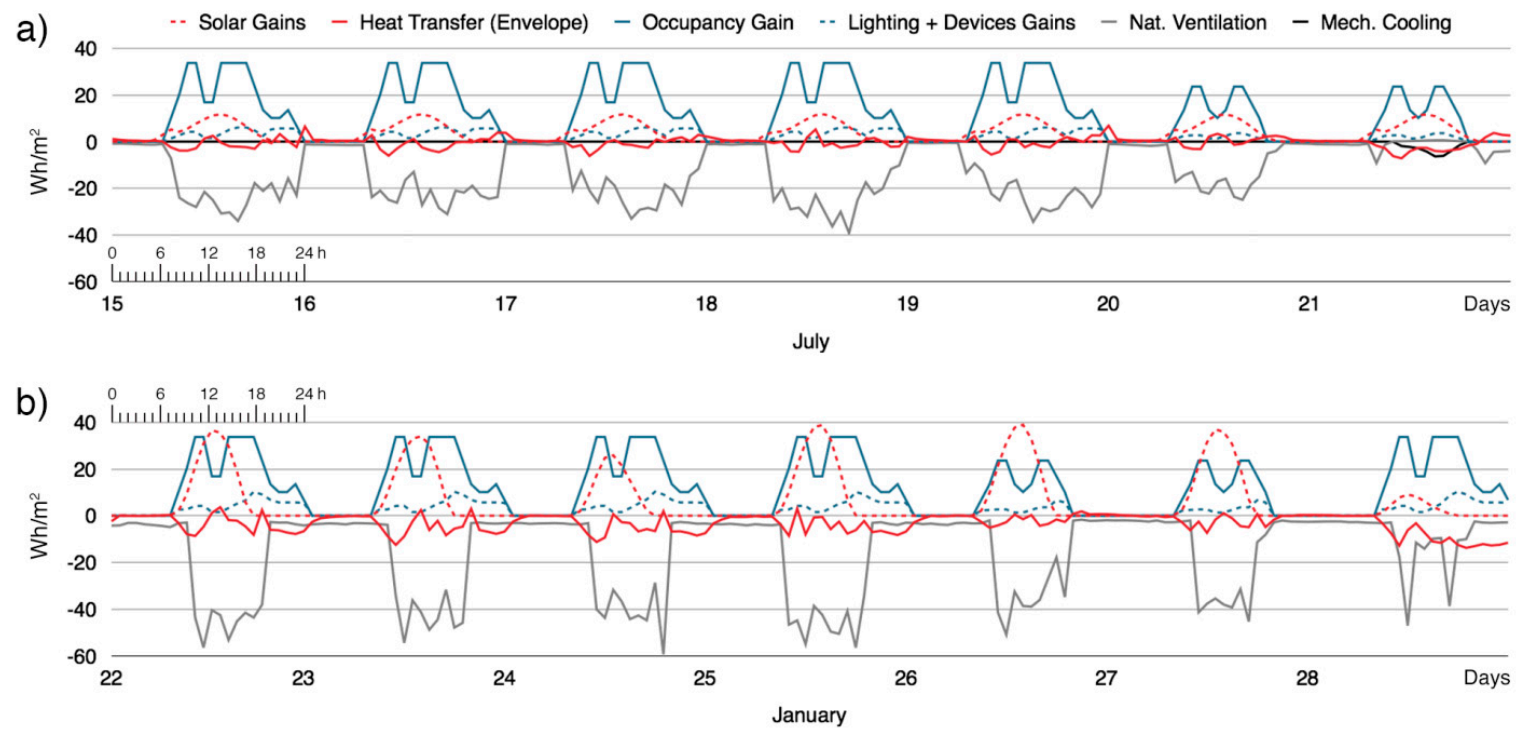

Figure 12. Scenario 5: Enhanced. Hourly Energy Balance: (a) July; and (b) January.

In this regard, Figure 13 contains the actual hourly air change rates due to natural ventilation; even though the air renewal rate is almost as close (if not higher) to the minimum levels contained in regulations (in this case, for the A1 thermal zone) natural ventilation will have to be supported by mechanical ventilation in order to avoid unpleasantly cold draughts and excessive air velocity. 


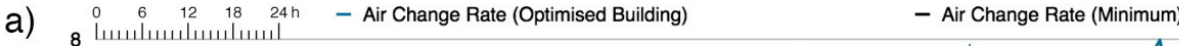

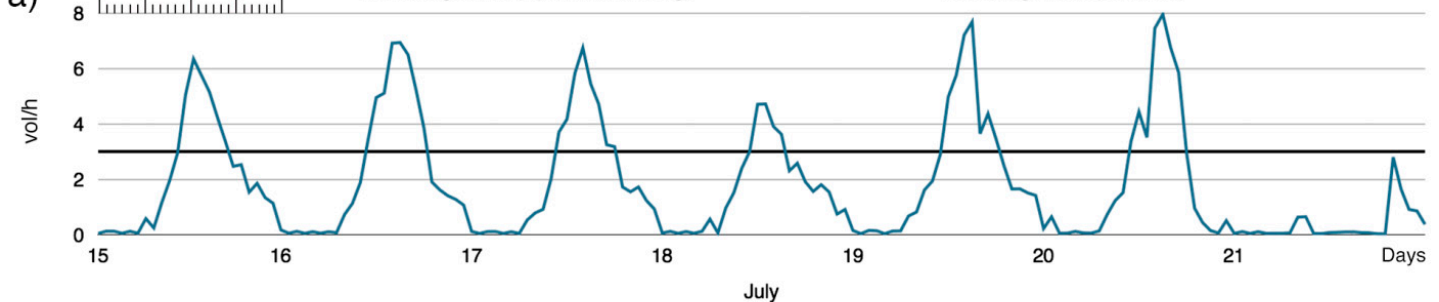

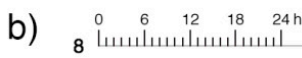

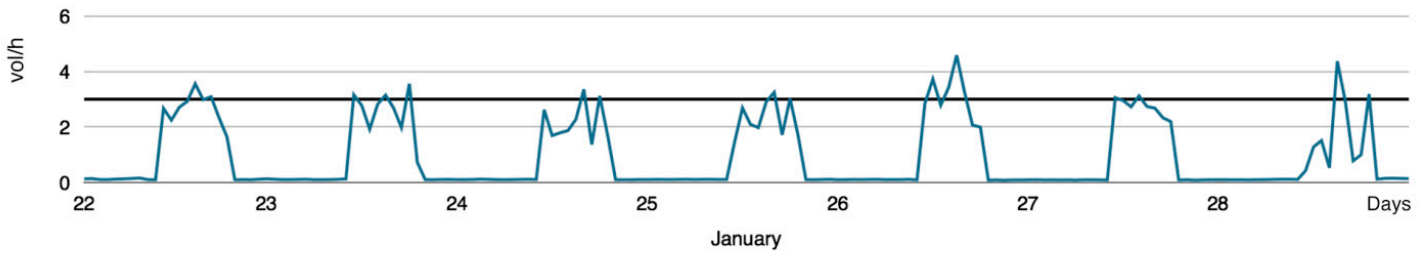

Figure 13. Scenario 5: Enhanced. Hourly Air Change Rate: (a) July; and (b) January.

\section{Conclusions}

The last century of human history has taught us that climate change is an issue that we can't ignore any longer, and that, on the contrary, we must strive to reach sustainability. For some thirty years, following in the footsteps of worldwide and international agreements, far-sighted legislators have been making a difference by calling for energy-efficient constructions and by promoting a shift in the people's mind-set.

Among other measures, the EU has recently introduced the Nearly Zero Energy Building, or "nZEB", a regulatory concept, whose proper definition has been left to national regulations. Beside this, however, voluntary systems, based either on performance or rating, have spread all over the place; the result is a very confusing state of affairs, as both systems fail to address the pressing issues that belong in the beginning of the design process.

Bioclimatic design, instead, looks at the subject from a different perspective; a context-based building, the result of an empirical expertise, takes advantage of the local environment, making do without complicated mechanical systems and relying instead on passive design. While frequently associated with low-tech construction or emergency architecture, this kind of design can indeed benefit from the integration with state-of-the-art technology, such as Building Automation Control Systems. This approach has been employed in the design of the new wing of Porto's School of Architecture; it comes in the shape of a partially underground building, which houses a new canteen, a study room and a parking lot. The energy simulation of this case-study building confirmed the previous assumption, as remarkable improvements in terms of indoor thermal comfort and energy end-use were achieved as soon as building automation was introduced.

The process reported in this paper, which introduces building automation and energy simulation into bioclimatic architectural design, can be scaled and repeated indefinitely, regardless of building size or type. In conclusion, it constitutes an important precedent to look to for any designer of energy-efficient buildings.

In order not to be distracted, some less relevant topics had to be disregarded; as such, they can be considered the starting point for further investigations. These include the optimization of the envelope assemblies, the effect of thermal bridges and that of ventilated thermal mass. As far as IEQ is concerned, $\mathrm{CO}_{2}$ levels shall be taken into account when it comes to natural ventilation; this, in turn, needs to be supported by mechanical systems in order to provide a steady ACH. Moreover, on-site energy generation must be investigated, in order to determine whether the building achieves an nZEB condition or not. 
Author Contributions: All the authors contributed in equal parts to the research activity and to the paper writing. Funding: This research received no external funding.

Acknowledgments: The Authors wish to acknowledge Arch. José Paulo Dos Santos, for his passionate and unconditional support during the earliest stages of the bioclimatic and architectural design of the case-study building.

Conflicts of Interest: The authors declare no conflict of interest.

\section{References}

1. United Nations Framework Convention on Climate Change, Kyoto Protocol, UN. Available online: https: / / unfccc.int/kyoto_protocol/items/2830.php (accessed on 19 December 2018).

2. European Environment Agency, EEA. Available online: https://www.eea.europa.eu (accessed on 19 December 2018).

3. Directive 2009/29/EC of the European Parliament and of the Council of 23 April 2009 so as to Improve and extend the greenhouse gas emission allowance trading scheme of the Community. Off. J. Eur. Union 2009, $140,63-87$.

4. Directive 2010/31/EU of the European Parliament and of the Council of 19 May 2010 (EPBD) on the Energy Performance of Buildings. Off. J. Eur. Union 2010, 153, 13-35.

5. Buildings Performance Institute Europe, BPIE, Nearly Zero Energy Buildings definitions across Europe. Available online: http://bpie.eu/publication/nzeb-definitions-across-europe-2015/ (accessed on 19 December 2018).

6. Marszal, A.J.; Heiselberg, P.; Bourrelle, J.S.; Musall, E.; Voss, K.; Sartori, I.; Napolitano, A. Zero Energy Building: A review of definitions and calculation methodologies. Energy Build. 2011, 43, 971-979. [CrossRef]

7. Penna, P.; Prada, A.; Cappelletti, F.; Gasparella, A. Multi-objective optimization for existing buildings retrofitting under government subsidization. Sci. Technol. Built Environ. 2015, 21, 847-861. [CrossRef]

8. Mattoni, B.; Guattari, C.; Evangelisti, L.; Bisegna, F.; Gori, P.; Asdrubali, F. Critical review and methodological approach to evaluate the differences among international green building rating tools. Renew. Sustain. Energy Rev. 2018, 82, 950-960. [CrossRef]

9. PassivHaus Institut. Available online: http:/ / www.passiv.de (accessed on 19 December 2018).

10. Mihai, M.; Tanasiev, V.; Dinca, C.; Badea, A.; Vidu, R. Passive house analysis in terms of energy performance. Energy Build. 2017, 144, 74-86. [CrossRef]

11. Rohdin, P.; Molin, A.; Moshfegh, B. Experiences from nine passive houses in Sweden e Indoor thermal environment and energy use. Build. Environ. 2014, 71, 176-185. [CrossRef]

12. Figueiredo, A.; Figueira, J.; Vicente, R.; Maio, R. Thermal comfort and energy performance: Sensitivity analysis to apply the Passive House concept to the Portuguese climate. Build. Environ. 2016, 103, $276-288$. [CrossRef]

13. Costanzo, V.; Fabbri, K.; Piraccini, S. Stressing passive behaviour of a Passivehaus: An evidence-based scenario analysis for a Mediterranean case study. Build. Environ. 2018, 142, 265-277. [CrossRef]

14. Colclough, S.; Kinnane, O.; Hewitt, N.; Griffiths, P. Investigation of nZEB social housing built to the Passive House standard. Energy Build. 2018, 179, 344-359. [CrossRef]

15. Figueiredo, A.; Kampf, J.; Vicente, R. Passive house optimization for Portugal: Overheating evaluation and energy performance. Energy Build. 2016, 118, 181-196. [CrossRef]

16. Leadership in Energy and Environmental Design, LEED. Available online: https:/ / new.usgbc.org (accessed on 19 December 2018).

17. Cost EFficient Passive Houses as EUropean Standards (C.E.P.H.E.U.S.), Community Research and Development Information Service (CORDIS). Available online: http:/ / cordis.europa.eu (accessed on 19 December 2018).

18. Barbosa, R.; Vicente, R.; Santos, R. Climate change and thermal comfort in Southern Europe housing: A case study from Lisbon. Build. Environ. 2015, 92, 440-451. [CrossRef]

19. Soutullo, S.; Sanchez, M.N.; Enriquez, R.; Olmedo, R.; Jimenez, M.J.; Heras, M.R. Comparative thermal study between conventional and bioclimatic office buildings. Build. Environ. 2016, 105, 95-103. [CrossRef] 
20. Rodriguez-Ubinas, E.; Montero, C.; Porteros, M.; Vega, S.; Navarro, I.; Castillo-Cagigal, M.; Matallanas, E.; Gutiérrez, A. Passive design strategies and performance of Net Energy Plus Houses. Energy Build. 2014, 83, 10-22. [CrossRef]

21. Ascione, F.; De Masi, R.F.; de Rossi, F.; Ruggiero, S.; Vanoli, G.P. Optimization of building envelope design for nZEBs in Mediterranean climate: Performance analysis of residential case study. Appl. Energy 2016, 183, 938-957. [CrossRef]

22. Synnefa, A.; Laskari, M.; Gupta, R.; Pisello, A.L.; Santamouris, M. Development of net zero energy settlements using advanced energy technologies. Energy Procedia 2017, 180, 1388-1401. [CrossRef]

23. Olgyay, V. Design with Climate: Bioclimatic Approach to Architectural Regionalism; Princeton University Press: Princeton, NJ, USA, 1963.

24. Tzikopoulos, A.F.; Karatza, M.C.; Paravantis, J.A. Modelling energy efficiency of bioclimatic buildings. Energy Build. 2005, 37, 529-544. [CrossRef]

25. Souza, E.; Archdaily. Faculty of Architecture of the University of Porto Through Fernando Guerra's Lenses. 2017. Available online: http:/ / www.archdaily.com (accessed on 19 December 2018).

26. Köppen, W. The geographic system of climate. In Handbook of Climatology; Gebrüder Bornträger: Berlin, Germany, 1936; Part 1-C.

27. Weather Data Sources, Energy. Available online: https://energyplus.net/weather/sources (accessed on 27 November 2017).

28. Irulegi, O.; Torres, L.; Serra, A.; Mendizabal, I.; Hernández, R. The Ekihouse: An energy self-sufficient house based on passive design strategies. Energy Build. 2014, 83, 57-69. [CrossRef]

29. Moita, F. Energia Solar Passive; Argomentum: Lisbona, Portugal, 2010.

30. Okeil, A. A holistic approach to energy efficient building forms. Energy Build. 2010, 42, 1437-1444. [CrossRef]

31. Caruso, G.; Fantozzi, F.; Leccese, F. Optimal theoretical building form to minimize direct solar irradiation. Sol. Energy 2013, 97, 128-137. [CrossRef]

32. Depecker, P.; Menezo, C.; Virgone, J.; Lepers, S. Design of buildings shape and energetic consumption. Build. Environ. 2001, 36, 627-635. [CrossRef]

33. Albatici, R.; Passerini, F. Bioclimatic design of buildings considering heating requirements in Italian climatic conditions: A simplified approach. Build. Environ. 2011, 46, 1624-1631. [CrossRef]

34. Ourghi, R.; Al-Anzi, A.; Krarti, M. A simplified analysis method to predict the impact of shape on annual energy use for office buildings. Energy Convers. Manag. 2007, 48, 300-305. [CrossRef]

35. Magrini, A.; Giobbi, L.; D’Ambrosio, F.R. Energy Audit of Public Buildings: The Energy Consumption of a University with Modern and Historical Buildings. Some Results. Energy Procedia 2016, 101, 169-175. [CrossRef]

36. Fantozzi, F.; Leccese, F.; Salvadori, G.; Rocca, M.; Garofalo, M. LED lighting for indoor sports facilities: Can its use be considered as sustainable solution from a techno-economic standpoint? Sustainability 2016, 8 , 618. [CrossRef]

37. Leccese, F.; Salvadori, G.; Casini, M.; Bertozzi, M. Analysis and measurements of artificial optical radiation (AOR) emitted by lighting sources found in offices. Sustainability 2014, 6, 5941-5954. [CrossRef]

38. Zhu, J.; Li, D. Current Situation of Energy Consumption and Energy Saving Analysis of Large Public Building. Procedia Eng. 2015, 121, 1208-1214. [CrossRef]

39. Nocera, F.; Lo Faro, A.; Costanzo, V.; Raciti, C. Daylight Performance of Classrooms in a Mediterranean School Heritage Building. Sustainability 2018, 10, 3705. [CrossRef]

40. Costanzo, V.; Evola, G.; Marletta, L.; Pistone Nascone, F. Application of Climate Based Daylight Modelling to Refurbishment of a School Building in Sicily. Sustainability 2018, 10, 2653. [CrossRef]

41. Costanzo, V.; Donn, M. Thermal and visual comfort assessment of natural ventilated office buildings in Europe and North America. Energy Build. 2017, 140, 210-223. [CrossRef]

42. Kazanasmaz, T.; Grobe, L.O.; Bauer, C.; Krehel, M.; Wittkopf, S. Three approaches to optimize optical properties and size of a South-facing window for spatial Daylight Autonomy. Build. Environ. 2016, 102, 243-256. [CrossRef]

43. Mohsenin, M.; Hu, J. Assessing daylight performance in atrium buildings by using Climate Based Daylight Modeling. Sol. Energy 2015, 119, 553-560. [CrossRef]

44. Leccese, F.; Salvadori, G.; Asdrubali, F.; Gori, P. Passive thermal behaviour of buildings: Performance of external multi-layered walls and influence of internal walls. Appl. Energy 2018, 225, 1078-1089. [CrossRef] 
45. Aste, N.; Angelotti, A.; Buzzetti, M. The influence of the external walls thermal inertia on the energy performance of well insulated buildings. Energy Build. 2009, 41, 1181-1187. [CrossRef]

46. Stazi, F.; Bonfigli, C.; Tomassoni, E.; Di Perna, C.; Munafó, P. The effect of high thermal insulation on high thermal mass: Is the dynamic behaviour of traditional envelopes in Mediterranean climates still possible? Energy Build. 2015, 88, 367-383. [CrossRef]

47. Leccese, F.; Salvadori, G.; Barlit, M. Ventilated flat roofs: A simplified model to assess their hygrothermal behaviour. J. Build. Eng. 2019, 22, 12-21. [CrossRef]

48. Ciampi, M.; Leccese, F.; Tuoni, G. Ventilated facades energy performance in summer cooling of buildings. Sol. Energy 2003, 75, 491-502. [CrossRef]

49. Wang, L.; Ma, P.; Hu, E.; Giza-Sisson, D.; Mueller, G.; Guo, N. A study of building envelope and thermal mass requirements for achieving thermal autonomy in an office building. Energy Build. 2014, 78, 79-88. [CrossRef]

50. Nicol, F.; Humphreys, M. Derivation of the adaptive equations for thermal comfort in free-running buildings in European standard EN15251. Build. Environ. 2010, 45, 11-17. [CrossRef]

51. Gratia, E.; Bruyère, I.; De Herde, A. How to use natural ventilation to cool narrow office buildings. Build. Environ. 2004, 39, 1157-1170. [CrossRef]

52. Capeluto, I.G. A methodology for the qualitative analysis of winds: Natural ventilation as a strategy for improving the thermal comfort in open spaces. Build. Environ. 2005, 40, 175-181. [CrossRef]

53. Kim, J.; Hong, T.; Jeong, J.; Lee, M.; Lee, M.; Jeong, K.; Koo, C. Establishment of an optimal occupant behaviour considering the energy consumption and indoor environmental quality by region. Appl. Energy 2017, 204, 1431-1443. [CrossRef]

54. Sun, K.; Hong, T. A framework for quantifying the impact of occupant behaviour on energy savings of energy conservation measures. Energy Build. 2017, 146, 383-396. [CrossRef]

55. Frontczak, M.; Wargocki, P. Questionnaire survey on factors influencing comfort with indoor environmental quality in Danish housing. Build. Environ. 2012, 50, 56-64. [CrossRef]

56. Meerbeek, B.; de Bakker, C.; de Kort, Y.A.W.; van Loene, E.; Bergman, T. Automated blinds with light feedback to increase occupant satisfaction and energy saving. Build. Environ. 2016, 103, 70-85. [CrossRef]

57. Bakker, L.G.; Hoes-van Oeffelen, E.C.M.; Loonen, R.C.G.M.; Hensen, J.L.M. User satisfaction and interaction with automated dynamic façades: A pilot study. Build. Environ. 2014, 78, 44-52. [CrossRef]

58. Crawley, D.B.; Hand, J.W.; Kummert, M.; Griffith, B.T. Contrasting the capabilities of building energy performance simulation programs. Build. Environ. 2008, 43, 661-673. [CrossRef]

59. Nicol, F.; Humphreys, M. Adaptive thermal comfort and sustainable thermal standards for buildings. Energy Build. 2002, 34, 563-572. [CrossRef]

60. Zomorodian, Z.S.; Tahsildoost, M.; Hafezi, M. Thermal comfort in educational buildings: A review article. Renew. Sustain. Energy Rev. 2016, 59, 895-906. [CrossRef]

61. Kim, J.; de Dear, R. Thermal comfort expectations and adaptive behavioural characteristics of primary and secondary school students. Build. Environ. 2018, 127, 13-22. [CrossRef]

62. Jiang, J.; Wang, D.; Liu, Y.; Xu, Y.; Liu, J. A study on pupils' learning performance and thermal comfort of primary schools in China. Build. Environ. 2018, 134, 102-113. [CrossRef]

63. Fabbri, K. Indoor Thermal Comfort Perception: A Questionnaire Approach Focusing on Children; Springer: London, UK, 2015.

64. Citterio, M.; Fasano, G. Indagine sui Consumi Degli Edifici Pubblici (Direzionale e Scuole) e Potenzialità Degli Interventi di Efficienza Energetica; Report RSE 165/2009; ENEA: Stockholm, Sweden, 2009.

(C) 2019 by the authors. Licensee MDPI, Basel, Switzerland. This article is an open access article distributed under the terms and conditions of the Creative Commons Attribution (CC BY) license (http://creativecommons.org/licenses/by/4.0/). 